\title{
Penilaian Kinerja Karyawan Berprestasi dengan Metode Simple Additive Weighting
}

\author{
Perani Rosyani $^{1}$, Normalisa ${ }^{1}$, Joko Priambodo ${ }^{1}$ \\ ${ }^{1}$ Program Studi Teknik Informatika, Fakultas Teknik, Universitas Pamulang, \\ Tanggerang Selatan, Indonesia.
}

Article History
Received:
29.04 .2019

Revised:
27.052019
Accepted:
16.06 .2019
*Corresponding Author:
Normalisa
Email:
dosen00377@unpam.ac.id

\section{Article History}

Received:

Revised:

Accepted:

16.06.2019

Normalisa

dosen00377@unpam.ac.id
Abstrak: PT. Matahari Putra Prima merupakan perusahaan yang cukup berkembang dibidang ritel di mana terdapat banyak karyawan yang dipekerjakan di sana. Penyeleksian karyawan berprestasi merupakan masalah yang sangat penting bagi pihak HRD karena perlimpahan karyawan untuk meningkatkan penghargaan untuk perusahaan tersebut. Untuk menentukan yang karyawan berprestasi ini, manajer harus mempertimbangkan lebih banyak faktor, dan pengajuannya harus dilakukan sesuai tujuan. Pengguna dapat memberikan hasil sesuai kebutuhan salah satu metode yang dapat digunakan adalah Simple Additive Weighting (SAW). Dari hasil penelitian dengan menggunakan metode SAW melalui pengumpulan hirarki dan atribut keputusan yang ditambahkan alternatif dan penilaian yang telah ditentukan akan memudahkan manajer dalam menentukan keputusan terhadap karyawan mana yang layak dipertimbangkan berprestasi. Untuk melakukan perhitungan semua kriteria dalam pengambilan keputusan ini, dilakukan dengan alat bantu aplikasi yang dikembangkan menggunakan bahasa pemrograman Java.

Kata Kunci: Simple Additive Weighting, Penilaian, Kinerja, Pengambilan Keputusan.

Performance Appraisal for Outstanding Employees Using the Simple Additive Weighting Method

Abstract: PT. Matahari Putra Prima is a well-developed company in the retail sector where there are many employees employed there. The selection of outstanding employees is a very important issue for the HRD because of the delegation of employees to increase appreciation for the company. The method that can be used is Simple Additive Weighting (SAW). From the results of the study using the SAW method through the collection of hierarchies and decision attributes that are added alternatives and predetermined assessments will facilitate managers in determining decisions on which employees are worth considering achievement. To calculate all the criteria in making this decision, it is done with application tools developed using the Java programming language.

Keyword: Simple Additive Weighting, Assessment, Performance, Decision Making. 


\section{Pendahuluan}

Penilaian kinerja adalah penentuan secara periodik efektivitas operasional suatuorganisasi, bagian organisasi dan karyawanya berdasarkan sasaran standar dankriteria yang telah ditetapkan sebelumnya [1]. Dari hasil penilaian kinerja karyawan dapat diketahui prestasi yang telah dicapai oleh setiap karyawan yaitu: sangat baik, baik sedang atau kurang. Penilaian prestasi penting bagi perusahaan untuk menetapkan tindakan kebijaksanaan perusahaan selanjutnya [2]. Sehingga dapat menentukan kelayakan bagi karyawan untuk mendapatkan penambahan insentif atau kenaikan gaji.

Sistem penilaian yang berjalan saat ini di PT. Matahari Putra Prima masih menggunakan metode rating scales di mana penilaian bersifat objektif dari atasan dengan kriteria yang telah ditentukan.Metode penilaian kinerja yang digunakan secara luas, yang menilai pekerja berdasar atas sejumlah faktor yang telah didefinisikan sebelumnya [3]. Akan tetapi rating scales ini memiliki beberapa kelemahan yaitu sulitnya menentukan factor-faktor yang relevan dalam pelaksanaan pekerjaan dan besarnya unsur subjektivitas yang dipakai penilai dalam melaksanakan rating scaleshasil penilaian cenderung bias [3].

Dari beberapa kelemahan tersebut, dapat disimpulkan bahwa metode rating scalesbelum efektif karena penilaiannya bersifat subyektif sehingga belum dapat memberikan analisa dan informasi yang akurat.

Rating scales adalah bentuk performance appraisal yang tertua. Teknik ini adalah bentuk performance appraisal yang tertua dan paling banyak digunakan, biasa dilakukan oleh atasan secara langsung [4]. Disamping itu juga terdapat permasalahan jika perusahaan ingin melakukan evaluasi kinerja karyawan dengan mempergunakan beberapa parameter, dimana parameter tersebut terdapat di dalam faktor penilaian dalam performance appraisal dan beberapa parameter lainnya bukan merupakan faktor penilaian dalam performance appraisal. Contoh kelompok parameter yang terdapat dalam faktor penilaian performance appraisal adalah: Store Operation, Leadership dan Attitude. Sedangkan beberapa parameter yang terdapat diluar faktor penilaian dalam performance appraisaladalah: data absensi karyawan, data peringatan, data penghargaan dan data hasil training. Oleh karena itu dibutuhkan suatu metode yang lebih efektif untuk melakukan penilaian terhadap kinerja karyawan dengan mempergunakan beberapa parameter tersebut [5].

Metode Simple Additive Weighting adalah salah satu metode yang dipergunakan untuk menyelesaikan permasalahan Multi Atribute Decision Making [6]. Konsep dasar dari metode Simple Additive Weighting adalah mencari penjumlahan terbobot dari rating kinerja pada setiap alternatif pada semua attribut.Yang mana metode SAW ini di implementasikan pada suatu perangkat lunak yaitu java netbeans.Dengan demikian Simple Additive Weighting dapat menanggulangi permasalahan pemilihan karyawan yang layak mendapatkan penambahan insentif dari perusahaan.

Penelitian yang menggunakan Simple Additive Weighting (SAW) diantaranya yaitu penelitian dari Heri Kiswanto [6] yang menyatakan bahwa hasil dari perhitungan sistem merupakan perangkingan nilai tertinggi ke rendah dan nilai tertinggi dalam menentukan penilaian kinerja karyawan di PT. ISTW Semarang. Penelitian oleh Mubarak [4] membuat sistem cerdas menggunakan konsep fuzzy logic untuk mengevaluasi kinerja karyawan dengan parameter performance appraisal yang sudah disetting, lakukan sistem penilaian dengan memasukkan nilai pada masing-masing kriteria detail appraisal. Nilai yang dimasukkan akan dikalkulasi berdasarkan batas atas dan batas bawah serta bobotnya.Penelitian oleh Maulana [7] menggunakan metode Analytical Hierarchy Process (AHP) dalam pengambilan sistem pendukung keputusan pada penilaian karyawan berprestasi menyatakan bahwa kriteria dan subkriteria di dalam penilaian karyawannya dengan mengacu dari beberapa kriteria yang telah di tentukan oleh pimpinan seperti kreativitas, disiplin, tanggung jawab,jujur, perilaku, komunikasi, kepemimpinan, dan adaptasi. Dan sub kriterianya seperti baik, cukup dan kurang.

Pada penelitian ini Simple Additive Weighting (SAW) di kolaborasikan pada java netbeans digunakan untuk mengolah penilaian kinerja karyawan untuk menentukan kelayakan penambahan insentif dari perusahaan.

Berdasarkan latar belakang masalah yang sudah dipaparkan diatas maka penulis merumuskan masalah bahwa metode rating scales memiliki beberapa permasalahan sehingga belum efektif dalam menilai kinerja karyawan.

Tujuan dari penelitian sistem penunjang keputusan dengan menggunakan metode Simple Additive Weighting yang diimplementasikan pada java netbeansdapat menghasilkan laporan kinerja karyawan dengan analisa dan informasi yang akurat sehingga dapat dipergunakan oleh perusahaan sebagai sistem penunjang keputusan. 
Manfaat dari penelitian ini antara lain; manfaat praktis dari hasil penelitian ini adalah diharapkan agar dapat digunakan oleh pihak manajemen untuk mengolah penilaian kinerja karyawan. Kemudian, manfaat teoritis dari hasil penelitian ini diharapkan dapat memberikan sumbangan penelitian yang berkaitan dengan metode Simple Additive Weighting. Terakhir, manfaat kebijakan manajemen dari hasil penelitian ini dapat digunakan sebagai bahan pertimbangan bagi Perusahaan untuk digunakan sebagai penunjang alat bantu dalam pengambilan keputusan atau kebijakan di institusinya

Dalam penelitian ini penulis membatasi pada pengkajian metode Simple Additive Weighting dan penggunaanya untuk kasus penilaian kinerja karyawan berdasarkan beberapa parameter yang ada dan kriteria yang berbeda.

\section{Landasan Teori}

Dalam penelitian ini, penulis melakukan studi literatur dengan mengumpulkan literatur, jurnal, paper dan bacaan-bacaan yang ada kaitannya dengana judul penelitian.

Penelitian pertama yang di lakukan oleh Heri Kiswanto, Susanto dan Nur Wakhidah [6] menggunakan Metode Fuzzy Multi Kriteria Decision Making dengan model Simple Additive Weight Method (SAW) untuk melakukan penilaian karyawan di PT. ISTW Semarang. Dalam jurnal ini, untuk menentukan penilaian kinerja karyawan di gunakan sepuluh variabel yang di jadikan karakter dalam dalam data input yang terdiri atas kualitas hasil kerja, kuantitas hasil kerja, pengetahuan tentang pekerjaan, tanggung jawab, kerja sama, jaringan kerja, inisiatif, disiplin kerja, integritas, kepedulian terhadap 5R dan safety. Berdasarkan kriteria-kriteria tersebut maka dapat menjabarkan pembobotan dalam penilaian kinerja karyawan. Output yang dihasilkan adalah nilai terbesar yang akan menjadi alternatif untuk menentukan karyawan terbaik dalam penilaiannya yang di implementasikan didalam sebuah software. Berdasarkan penelitian yang di lakukan oleh Heri Kiswanto, Susanto dan Nur Wakhidah [6], mereka menyimpulkan bahwa perhitungan pada sistem untuk melakukan penyeleksian menggunakan metode SAW (Simple Additive Weight Method) merupakan perangkingan nilai tertinggi ke rendah dan sistem yang dibangun hanya sebagai alat bantu untuk memberikan informasi kepada pimpinan perusahaan sebagai bahan pertimbangan dalam mengambil keputusan dan diharapkan dapat mewujudkan sebuah penilaian yang adil berdasarkan kriteria yang telah ditentukan oleh perusahaan.

Penelitian kedua yang dilakukan oleh Karman Maulana [7] yang membahas bagaimana membangun suatu Sistem Pendukung Keputusan Penilaian Karyawan Berprestasi Berdasarkan Kinerja Berbasis Web dengan menggunakan metode Analytical Hierarchy Proses (AHP). Dengan menggunakan delapan kriteria yaitu kreativitas, disiplin, tanggung jawab, jujur, perilaku, komunikasi, kepemimpinan, dan adaptasi. Output yang dihasilkan adalah nilai terbaik yang akan menjadi penentu karyawan terbaik. Data yang diperoleh dalam penelitian ini berasal dari PT. Anindya Mitra Internasional Yogyakarta. Berdasarkan dari penelitian ini dapat disimpulkan bahwa Sistem Pendukung Keputusan Penilaian Karyawan Berprestasi Berbasis Web Menggunakan Metode Analytical Hierarchy Proses (AHP) cukup efektif karena di implementasikan dalam sebuah sistem web dan sistem pendukung keputusan ini dapat dibuat untuk sistem pendukung keputusan kenaikan jabatan

Penelitian ketiga yang dilakukan oleh Emil Widyaracmawati [13] membahas bagaimana proses penilaian kinerja di PT. Persero Angkasa Pura I Bandar Udara Juanda Surabaya menjadi lebih cepat dan mengurangi subyektifitas dalam proses penilaian serta membantu pihak manajemen dalam mengambil keputusan untuk memberikan reward berdasarkan kinerja karyawan dan kriteria-kriteria yang telah ditetapkandengan lebih cepat dan objektif sesuai dengan metode Simple Additive Weighting yang diterapkan. Output yang dihasilkan adalah nilai terbaik yang akan menjadi penentu karyawan terbaik. Data yang di peroleh dalam penelitian ini berasal dari PT. Persero Angkasa Pura I Bandar Udara Juanda Surabaya.Berdasarkan dari penelitian ini dapat disimpulkan bahwa Aplikasi yang dibuat dapat digunakan manajemen dalam melakukan Penilaian Kinerja pada PT. Persero Angkasa Pura I Bandar Udara Juanda Surabaya dengan faktor (kriteria) dan pedoman item penilaian kualitas yang telah ditentukan dan Sistem dapat menghasilkaninformasi penilaian kinerjakaryawan yang membantu danmempermudah manajemen dalammengambil keputusan.

\subsection{Fuzzy Multiple Attribute Decision Making}

Fuzzy Multiple Attribute Decision Making (FMADM) adalah suatu metode yang digunakan untuk mencari alternatif optimal dari sejumlah alternatif dengan kriteria tertentu. Metode ini diciptakan 
untuk mengatasi kelemahan dari metode-metode Multi Attribute Decision Making (MADM) klasik [14].

Salah satu cara yang dapat digunakan untuk menyelesaikan permasalahan tersebut adalah dengan menggunakan Fuzzy Multiple Attribute Decision Making (FMADM). Inti dari FMADM adalah menentukan nilai bobot untuk setiap atribut, kemudian dilanjutkan dengan proses perankingan yang akan menyeleksi alternatif yang sudah diberikan. Terdapat beberapa metode yang dapat digunakan untuk menyelesaikan masalah FMADM, antara lain Simple Additive Weighting Method (SAW), Weighted Product (WP), Technique for Order Preference by Similarity to Ideal Solution (TOPSIS), dan Analytic Hierarchy Process (AHP) [15].

\subsection{Simple Additive Weighting}

Metode Simple Additive Weighting (SAW) sering juga dikenal istilah metode penjumlahan terbobot. Konsep dasar metode SAW adalah mencari penjumlahan terbobot dari rating kinerja pada setiap alternatif pada semua atribut. Metode SAW membutuhkan proses normalisasi matriks keputusan (X) ke suatu skala yang dapat diperbandingkan dengan semua rating alternatif yang ada.

Metode ini merupakan metode yang paling dikenal dan paling banyak digunakan orang dalam menghadapi situasi MADM (multiple attribute decision making). Metode ini mengharuskan pembuat keputusan menentukan bobot bagi setiap atribut. Skor total untuk sebuah alternatif diperoleh dengan menjumlahkan seluruh hasil perkalian antara rating (yang dapat dibandingkan lintas atribut) dan bobot tiap atribut. Rating tiap atribut haruslah bebas dimensi yang artinya telah melewati proses normalisasi sebelumnya [16].

Menurut Kusumadewi [17], langkah-langkah penelitian dalam menggunakan metode SAW, adalah:

1. Menentukan kriterian-kriteria yang akan dijadikan acuan dalam pengambilan keputusan, yaitu Ci.

2. Menentukan rating kecocokan setiap alternatif pada setiap kriteria.

3. Membuat matriks keputusan berdasarkan kriteria (Ci), kemudian melakukan normalisasi matriks berdasarkan persamaan yang disesuaikan dengan jenis atribut (atribut keuntungan maupun atribut biaya) sehingga diperoleh matriks ternormalisasi R.

Hasil akhir diperoleh dari setiap proses perankingan yaitu penjumlahan dari perkalian matriks ternormalisasi $\mathrm{R}$ dengan vector bobot sehingga diperoleh nilai terbesar yang dipilih sebagai alternatif terbaik (Ai) sebagai solusi [18].

\subsection{Kinerja Karyawan}

Suyadi Prawirosentono [19] menyatakan Kinerja adalah hasil kerja yang dapat dicapai oleh seseorang atau kelompok orang dalam suatu organisasi sesuai dengan wewenang dan tanggung jawab masingmasing dalam rangka upaya mencapai tujuan organisasi bersangkutan secara legal tidak melanggar hukum dan sesuai dengan moral maupun etika. Muhammad Zainur [20] mendefinisikan "Kinerja merupakan keseluruhan proses bekerja dari individu yang hasilnya dapat digunakan landasan untuk menentukan apakah pekerjaan individu tersebut baik atau sebaliknya". Kinerja juga merupakan keluaran yang dihasilkan oleh fungsi-fungsi atau indikator suatu pekerjaan atau suatu profesi dalam waktu tertentu [21]. Sementara itu, Malayu Hasibuan [2] mendefinisikan karyawan sebagai penjual jasa (pikiran dan tenaga) dan mendapatkankompensasi yang besarnya telah ditetapkan terlebih dahulu.

Menurut Dale Timple (2000) dalam Siti Munafiah [14] terdapat dua faktor yang mempengaruhi Kinerja Karyawan yaitu faktor internal dan faktor eksternal.Faktor internal adalah faktor-faktor yang berhubungan dengan sifat-sifat seseorang meliputi sikap, sifat kepribadian, sifat fisik, motivasi, umur, jenis kelamin, pendidikan, pengalaman kinerja, latar belakang budaya, dan variabel personal lainnya.Faktor eksternal adalah faktor-faktor yang mempengaruhi kinerja karyawan yang berasal dari lingkungan meliputi kebijakan organisasi, kepemimpinan, tindakantindakan rekan kerja, pengawasan, sistem upah, dan lingkungan sosial.

Menurut Richard I. Handerson (1984) dalam Wirawan [13], "dimensi kinerja adalah kualitaskualitas atau wajah suatu pekerjaan atau aktivitas- aktivas yang terjadi di tempat kerja yang konduktif terhadap pengukuran". Dimensi kinerja menyediakan alat untuk melukiskan keseluruhan cakupan aktivitas di tempat kerja. Sementara itu, tanggung jawab dan kewajiban menyediakan suatu deskripsi 
depersonalisasi. Sedangkan dimensi kinerja dikelompokkan menjadi tiga jenis yaitu hasil kerja, perilaku kerja, dan sifat pribadi yang berhubungan dengan pekerjaan [14].

\subsection{Unified Modelling Language}

Unified Modeling Language (UML) merupakan sistem arsitektur yang bekerja dalam OOAD (ObjectOriented Analysis/Design) dengan satu bahasa yang konsisten untuk menentukan, visualisasi, mengkontruksi, dan mendokumentasikan artifact (sepotong informasi yang digunakan atau dihasilkan dalam suatu proses rekayasa software, dapat berupa model, deskripsi, atau software) yang terdapat dalam sistem software.UML merupakan bahasa pemodelan yang paling sukses dari tiga metode OO yang telah ada sebelumnya, yaitu Booch, OMT (Object Modeling Technique), dan OOSE (ObjectOriented Software Engineering).

$U M L$ tidak hanya merupakan sebuah bahasa pemograman visual saja, namun juga dapat secara langsung dihubungkan ke berbagai bahasa pemograman, seperti JAVA, C++, Visual Basic, atau bahkan dihubungkan secara langsung ke dalam sebuah object-oriented database. Begitu juga mengenai pendokumentasian dapat dilakukan seperti; requirements, arsitektur, design, source code, project plan, tests, dan prototypes.

UML sendiri terdiri atas pengelompokkan diagram-diagram sistem menurut aspek atau sudut pandang tertentu. Diagram adalah yang menggambarkan permasalahan maupun solusi dari permasalahan suatu model. UML mempunyai 9 diagram, yaitu; use-case, class, object, state, sequence, collaboration, activity, component, dan deployment diagram.

\subsection{Bahasa Pemrograman Java}

Versi pertama bahasa pemrograman Java dirilis pada akhir 1995, dan dalam beberapa bulan Java menjadi bahasa pemrograman pada World Wide Web.Beberapa tahun kemudian merupakan salah satu bahasa pemrograman serbaguna yang pernah dikembangkan dan banyak digunakan. Java memiliki beberapa keunggulan bila dibandingkan dengan bahasa pemrograman lainnya. Diantaranya [15]:

1. Java bersifat lebih sederhana dan relatif mudah. Java dimodelkan sebagian dari bahasa $\mathrm{C}++$, namun dengan memperbaik beberapa karakteristik $\mathrm{C}++$, seperti mengurangi kompleksitas beberapa fitur, penambahan fungsionalitas, serta penghilangan beberapa aspek pemicu ketidakstabilan sistem pada $\mathrm{C}++$.

2. Java berorientasi objek.Java adalah bahasa pemrograman berorientasi objek (OOP), yang dimaksud dengan pemrograman berorientasi objek adalah suatu konsep pemrograman yang memecahkan masalah dengan cara memilah program menjadi objek-objek yang saling berinteraksi satu sama lain.

3. Java bersifat multiplatform, dapat diterjemahkan oleh Java interpreter pada berbagai sistem operasi.

4. Java bersifat multithrea.Thread adalah proses yang dapat dikerjakan oleh program dalam suatu waktu. Ini berarti Java dapat mengerjakan beberapa proses dalam waktu yang hampir bersamaan.

Program java dapat dibedakan menjadi dua jenis, yaitu applet dan aplikasi [16]:

1. Applet adalah program yang dibuat dengan java, dapat diletakkan pada web server dan diakses melalui web browser. Dalam hal ini browser yang digunakan adalah memiliki kemampuan java (misalnya Netscape Navigator, internet Explorer, dan HotJava).

2. Aplikasi adalah program yang dibuat dengan java yang bersifat umum. Aplikasi dapat dijalankan secara langsung, tidak perlu perangkat lunak browser untuk menjalankannya. Aplikasi dapat anda bayangkan seperti program yang anda tulis dengan bahasa $\mathrm{C}$ atau Pascal. Setelah dikompilasi, anda dapat mengeksekusinya secara langsung.

\subsection{Netbeans}

Netbeans adalah sebuah proyek software OpenSource. Proyek Netbeans mulai diprakarsai oleh Perusahaan Sun Microsystems sejak bulan Juni 2000 dan terus berkembang hingga saat ini. NetBeans mengacu pada dua hal, yaitu NetBeans platform untuk pengembangan aplikasi desktop java dan sebuah NetBeans IDE (Integrated Development Environment).

IDE Netbeans memiliki editor untuk file Java yang berbasiskan teks ataupun GUI (Graphical User Interface). Ada bermacam-macam proyek file Java yang dapat dibuat di dalam Netbeans. Netbeans yang berisi sebuah aplikasi GUI Java yang bertujuan sebagai sarana untuk memperkenalkan fitur 
editor teks dari IDE Netbeans. Netbeans sebagai IDE ditujukan untuk memudahkan pemrograman Java. Dalam Netbeans, pemrograman dilakukan berbasiskan visual dan event driven. Seperti IDE lain, misalnya Borland Delphi dan Microsoft Visual Studio. Untuk membuat dialog atau User Interface, kita tidak perlumembuat teks program secara manual baris per baris, tetapi cukup klik pada component pallete. Teks program akan dihasilkan secara otomatis.

\section{Metode Penelitian}

\subsection{Analisis Sistem Berjalan}

Analisis sistem berjalan bertujuan untuk menganalisa sistem yang saat ini sedang digunakan pada penilaian kinerja karyawan di dalam perusahaan ini.

1. Bagian HRD akan memberikan sebuah form berisi angket untuk diisi oleh useratau manager dari tiap-tiap bagian di setiap semester.

2. Angket tersebut di isi sesuai dengan pengamatan user selama ini.

3. Dan setelah di isi di berikan kepada kepala divisi untuk di cek ulang, jika penilaian menurut kepala divisi memang sesuai di tanda tangani lalu kemudian di kembalikan lagi ke HRD untuk di proses lebih lanjut.

Adapun kelebihan dan kelemahan pada Sistem Berjalan yakni:

a. Kelebihan

- Mudah beradaptasi terhadap perubahan kondisi lingkungan.

b. Kelemahan

- Pengambilan keputusan kurang efektif dan efisien.

- Kondisi emosional pengambil keputusan sangat mempengaruhi hasil keputusan.

- Hasil keputusan kurang dapat dipertanggung jawabkan karena tidak adanya sistem yang secara pasti memberikan hasil keputusan.

Sistem yang dipakai pada penilaian dalam pengambilan keputusan semuanya dilakukan secara manual. Untuk menghasilkan keputusan yang lebih efektif dan efisien dalam pengambilan keputusan penilaian kinerja kerja, diperlukan suatu sistem pengambilan keputusan dengan membangun sebuah aplikasi menggunakan metode Simple Additive Weighting (SAW).

\subsection{Perancangan Sistem Usulan}

Merancang sebuah aplikasi sistem pendukung keputusan dengan menggunakan metode Simple Additive Weighting (SAW)yang dapat digunakan untuk mengambil keputusan penilaian kinerja karyawan. Dengan sistem usulan ini diharapkan dapat menghindari kelemahan-kelemahan dalam sistem berjalan.

Kelebihan Sistem Usulan:

- Membantu pengambil keputusan dalam hal penghematan waktu yang dibutuhkan untuk memecahkan masalah.

- Dapat menyediakan bukti tambahan untuk memberikan pembenaran sehingga dapat memperkuat posisi pengambil keputusan.

- Sistem yang interaktif yang membantu pengambil keputusan penggunaan data dan model.

Prosedur pengambilan Keputusan Sistem Usulan

- Admin atau bagian HRD menginput jenis penilaian yang ada lalu di berikan kepada user.

- User tinggal menginput nilai berdasarkan kriteria yang telah di tentukan.

- Setelah selesai user menyerahkan kembali kepada admin untuk dapat dilakukan pengambilan keputusan dengan menggunakan metode SAW sebagai SPK

Pengambilan keputusan melakukan proses komunikasi dengan subsistem antar muka yang telah disediakan. Unit manager atau bagian yang ditunjuk dapat melakukan pengolahan data dan member perintah pada sistem untuk mengolah data yang ada sesuai model yang digunakan dan meminta sistem member alternatif solusi setelah dimasukkan beberapa kriteria dan bobot yang diperhitungkan. 
Keluaran informasi sistem bisa dijadikan pertimbangan untuk menilai kinerja kerja karyawan dengan menggunakan metode SAW.

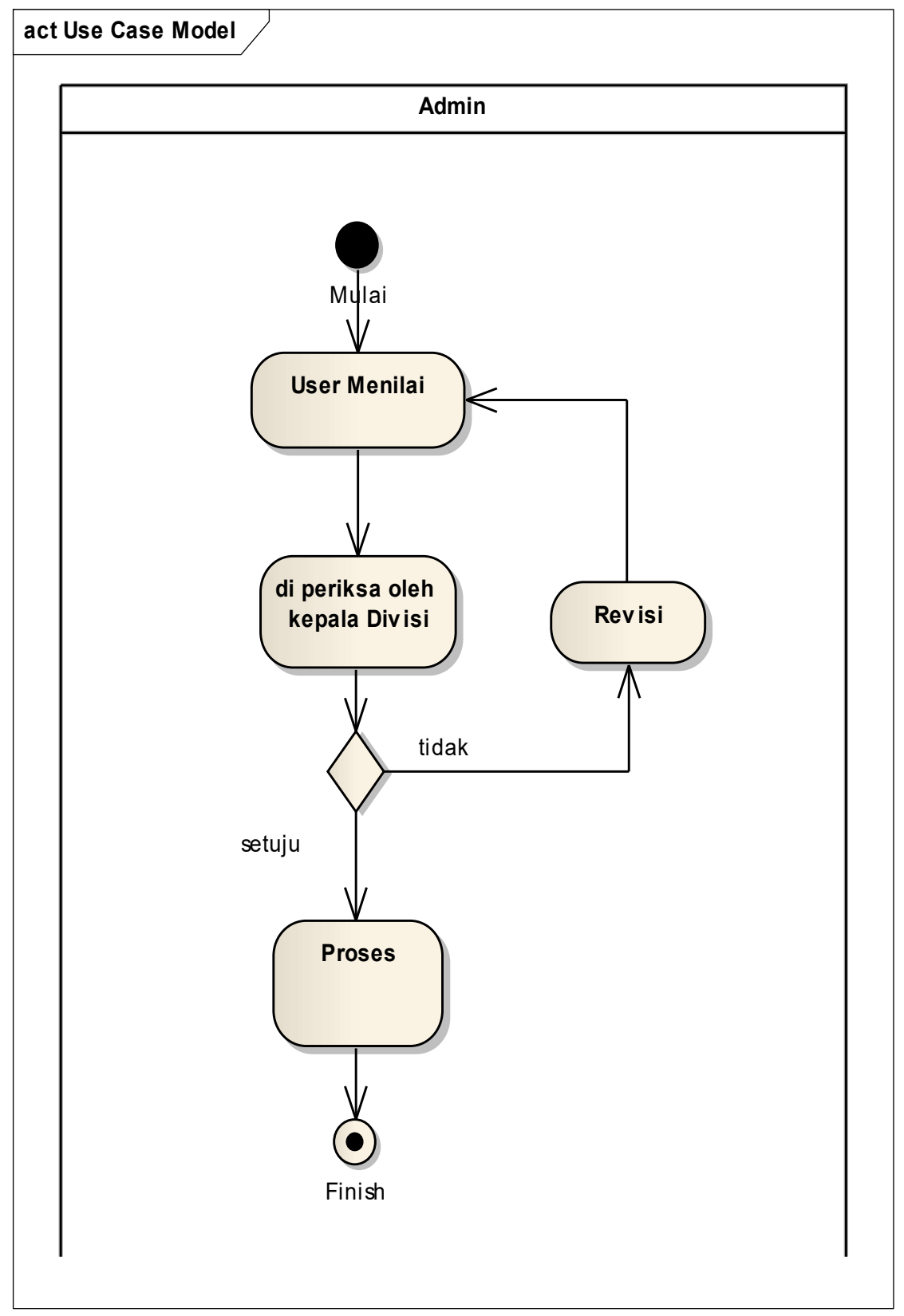

Gambar 1. Sistem Berjalan

\subsection{Penerapan Metode Simple Additive Weighting}

Dalam metode FMADM dengan metode SAW terdapat kriteria yang dibutuhkan untuk menentukan siapa yang akan terseleksi sebagai karyawan terbaik.

Adapun kriterianya bisa dilihat pada Tabel 1 . 


\section{Tabel 1. Tabel Kriteria}

\begin{tabular}{|l|l|}
\hline Kriteria & Keterangan \\
\hline C1 & Absensi \\
\hline C2 & Tanggung Jawab \\
\hline C3 & Disiplin \\
\hline C4 & Target Yang Dicapai \\
\hline C5 & Kerja Sama \\
\hline C6 & Inisiatif \\
\hline
\end{tabular}

Dari masing-masing kriteria tersebut akan ditentukan bobot-bobotnya. Pada bobot terdiri dari empat bilangan fuzzy, yaitu:

- $\operatorname{Kurang}$ Baik $(\mathrm{KB}) \quad=1$

- $\operatorname{Kurang}(\mathrm{K}) \quad=2$

- $\operatorname{Cukup}(\mathrm{C})=3$

- Baik (B) = 4

- Sangat Baik (SB) $=5$

Nilai bobot tersebut dibuat dalam bentuk grafik yang ditunjukan pada grafik dibawah ini:

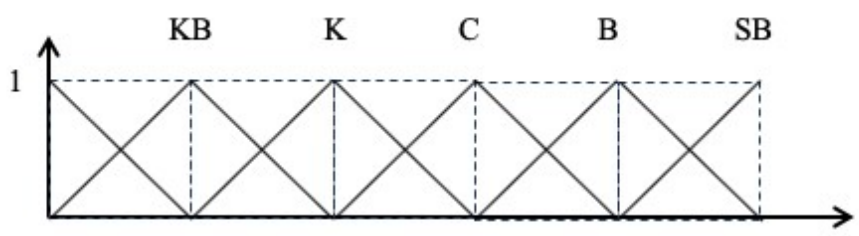

Keterangan:

$\mathrm{KB} \quad=$ Kurang Baik;

$\mathrm{K} \quad=$ Kurang;

$\mathrm{C} \quad=$ Cukup;

$\mathrm{B} \quad=$ Baik;

$\mathrm{SB} \quad=$ Sangat Baik.

Dan untuk rating kepentingannya yang akan digunakan sebagai standar ddari penilaian yang diharapkan dari setiap kriteria:

- Kurang Penting (KP) $=1$

- $\operatorname{Kurang}(\mathrm{K}) \quad=2$

- $\operatorname{Cukup}(\mathrm{C}) \quad=3$

- $\operatorname{Tinggi(\mathrm {T})\quad =4}$

- Sangat Tinggi (ST) $=5$

Berdasarkan kriteria dan rating kecocokan setiap alternative (Karyawan) pada setiap kriteria yang telah ditentukan, selanjutnya penjabaran bobot dari setiap kriteria yang telah di konversikan dengan bilangan fuzzy. 
Kriteria yang di gunakan dalam penilaian kinerja karyawan PT. MPP adalah sebagai berikut:

a. Total Absensi (C1)

Total keterlambatan datang adalah total di mana absen di luar waktu yang telah di tentukan oleh pihak manajemen perusahaan.

Rating Kepentingan: Sangat Tinggi (ST)

\section{Tabel 2. Rating Kecocokan Absensi}

\begin{tabular}{|l|l|l|}
\hline No. & Absensi & Nilai \\
\hline 1 & Sangat Baik & 5 \\
\hline 2 & Baik & 4 \\
\hline 3 & Cukup & 3 \\
\hline 4 & Kurang & 2 \\
\hline 5 & Kurang Baik & 1 \\
\hline
\end{tabular}

b. Tanggung Jawab (C2)

Rasa Tanggung jawab karyawan terhadap tugas yang sudah menjadi pekerjaannya.

Rating Kepentingan: Tinggi (T)

Tabel 3. Rating Kecocokan Tanggung Jawab

\begin{tabular}{|l|l|l|}
\hline No. & Tanggung Jawab & Nilai \\
\hline 1 & Sangat Baik & 5 \\
\hline 2 & Baik & 4 \\
\hline 3 & Cukup & 3 \\
\hline 4 & Kurang & 2 \\
\hline 5 & Kurang Baik & 1 \\
\hline
\end{tabular}

c. Disiplin (C3)

Pemahaman dan pelaksanaan terhadap peraturan perusahaan.

Rating Kepentingan: Tinggi (T)

Tabel 4. Rating Kecocokan Disiplin Kerja

\begin{tabular}{|l|l|l|}
\hline No. & Disiplin Kerja & Nilai \\
\hline 1 & Sangat Baik & 5 \\
\hline 2 & Baik & 4 \\
\hline 3 & Cukup & 3 \\
\hline 4 & Kurang & 2 \\
\hline 5 & Kurang Baik & 1 \\
\hline
\end{tabular}


d. Target Yang Dicapai (C4)

Target yang dicapai adalah ukuran hasil dari pekerjaan yang telah di tetapkan baik dari perusahaan maupun diri sendiri.

Rating Kepentingan: Sangat Tinggi (ST)

Tabel 5. Rating Kecocokan Target Yang Dicapai

\begin{tabular}{|l|l|l|}
\hline No. & Target Yang di Capai & Nilai \\
\hline 1 & Sangat Baik & 5 \\
\hline 2 & Baik & 4 \\
\hline 3 & Cukup & 3 \\
\hline 4 & Kurang & 2 \\
\hline 5 & Kurang Baik & 1 \\
\hline
\end{tabular}

e. Kerja Sama (C5)

Kemampuan untuk bekerja secara bersama dengan rekan kerja

Rating Kepentingan: Tinggi (T)

Tabel 6. Rating Kecocokan Kerja Sama

\begin{tabular}{|l|l|l|}
\hline No. & Kerja Sama & Nilai \\
\hline 1 & Sangat Baik & 5 \\
\hline 2 & Baik & 4 \\
\hline 3 & Cukup & 3 \\
\hline 4 & Kurang & 2 \\
\hline 5 & Kurang Baik & 1 \\
\hline
\end{tabular}

f. Inisiatif (C6)

Kemampuan untuk mengungkapkan ide.

Rating Kepentingan: Tinggi (T)

Tabel 7. Rating Kecocokan Inisiatif

\begin{tabular}{|l|l|c|}
\hline No. & Inisiatif & Nilai \\
\hline 1 & Sangat Baik & 5 \\
\hline 2 & Baik & 4 \\
\hline 3 & Cukup & 3 \\
\hline 4 & Kurang & 2 \\
\hline 5 & Kurang Baik & 1 \\
\hline
\end{tabular}


Dalam aplikasi yang dikembangkan untuk setiap nilai yang diberikan oleh setiap alternative disetiap kriteria merupakan nilai kecocokan (nilai terbesar adalah terbaik), maka semua kriteria yang diberikan diasumsikan sebagai kriteria keuntungan. Sehingga persamaan yang digunakan adalah Persamaan 1.

$$
r=\frac{x_{i j}}{\operatorname{Max}_{i} x_{i j}}
$$

\section{Keterangan:}

$r_{i j} \quad=$ nilai rating kinerjaternormalisasi

$x_{i j} \quad=$ nilaiatribut yang dimilikidarisetiapkriteria

$\operatorname{Max}_{i} \quad=$ nilaiterbesardarisetiap kriteria

Nilai preferensi untuk setiap alternative $\left(V_{i}\right)$ diberikan sebagai:

$$
V_{i}=\sum_{j=1}^{n} w_{j} r_{i j}
$$

Nilai $V_{i}$ yang lebih besar mengindikasikan bahwa alternative $A_{i}$ lebih terpilih.

Berikut merupakan contoh penyelesaian masalah menggunakan metode SAW berdasarkan data di atas:

Proses Penilaian Kinerja Karyawan bernama Rosa dimana karyawan akan di nilai oleh:

K-1 = Hendra Himawan (jabatan GM),

K-2 = Elly Dorothy (jabatan Manager),

K-3 = Ratna (jabatan Supervisor).

Dan ketiganya telah memberikan nilai seperti pada Tabel 8.

Tabel 8. Rating Kecocokan Setiap Alternative pada setiap kriteria

\begin{tabular}{|l|r|r|r|r|r|r|}
\hline \multirow{2}{*}{ Alternatif } & \multicolumn{7}{|c|}{ Hasil Penilaian } \\
\cline { 2 - 7 } & \multicolumn{1}{|c|}{ C1 } & \multicolumn{1}{l|}{ C2 } & \multicolumn{1}{l|}{ C3 } & C4 & C5 & \multicolumn{1}{l|}{ C6 } \\
\hline K-1 & 2 & 3 & 4 & 3 & 4 & 4 \\
\hline K-2 & 3 & 3 & 4 & 4 & 5 & 3 \\
\hline K-3 & 5 & 2 & 5 & 5 & 5 & 5 \\
\hline
\end{tabular}


Dimana pihak manajemen telah menentukan bobot preferensi (Standar Nilai) yang merupakan rating kepentingan sebagai berikut:

Tabel 9. Rating Kepentingan Setiap Kriteria

\begin{tabular}{|l|c|c|c|c|c|c|}
\hline Kriteria & C1 & C2 & C3 & C4 & C5 & C6 \\
\hline $\begin{array}{l}\text { Rating } \\
\text { Kepentingan }\end{array}$ & 5 & 4 & 4 & 4 & 4 & 4 \\
\hline
\end{tabular}

Penyelesaian:

Langkah Pertama

Matriks yang terbentuk dari tabel kecocokan dalahm hal ini tabel 3.9, sebagai berikut:

$$
X=\left(\begin{array}{llllll}
2 & 3 & 4 & 3 & 4 & 4 \\
3 & 3 & 4 & 4 & 5 & 3 \\
5 & 2 & 5 & 5 & 5 & 5
\end{array}\right)
$$

Pengambil keputusan memberikan standar berdasarkan tabel 3.10 sebagai berikut:

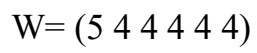

Langkah kedua

Lakukan normalisasi matriks $\mathrm{X}$ berdasarkan rumus persamaan sebagai berikut:

$$
\begin{aligned}
& \mathrm{K}-1: r_{11}=\frac{2}{\operatorname{Max}\{2 ; 3 ; 5\}}=\frac{2}{5}=0.4 \\
& \mathrm{~K}-2: r_{21}=\frac{3}{\operatorname{Max}_{i}\{2 ; 3 ; 5\}}=\frac{3}{5}=0.6 \\
& r_{12}=\frac{3}{\operatorname{Max}\{3 ; 3 ; 2 ;\}}=\frac{3}{3}=1 \\
& r_{22}=\frac{3}{\operatorname{Max}\{3 ; 3 ; 2\}}=\frac{3}{3}=1 \\
& r_{13}=\frac{4}{\operatorname{Max}_{i}\{4 ; 4 ; 5\}}=\frac{4}{5}=0.8 \\
& r_{23}=\frac{4}{\operatorname{Max}_{i}\{4 ; 4 ; 5\}}=\frac{4}{5}=0.8 \\
& r_{14}=\frac{3}{\operatorname{Max}_{i}\{3 ; 4 ; 5\}}=\frac{3}{5}=0.6 \\
& r_{24}=\frac{4}{\operatorname{Max}\{3 ; 4 ; 5\}}=\frac{4}{5}=0.8 \\
& r_{15}=\frac{4}{\operatorname{Max}_{i}\{4 ; 5 ; 5\}}=\frac{4}{5}=0.8 \\
& r_{25}=\frac{5}{\operatorname{Max}\{4 ; 5 ; 5\}}=\frac{5}{5}=1 \\
& r_{16}=\frac{4}{\operatorname{Max}\{4 ; 3 ; 5\}}=\frac{4}{5}=0.8 \\
& r_{26}=\frac{3}{\operatorname{Max}_{i}\{4 ; 3 ; 5\}}=\frac{3}{5}=0.6
\end{aligned}
$$


Berdasarkan hasil normalisasi matriks X maka terbentuklah matriks R sebagai berikut:

$$
\mathrm{R}=\left(\begin{array}{llllll}
0.4 & 1 & 0.8 & 0.6 & 0.8 & 0.8 \\
0.6 & 1 & 0.8 & 0.8 & 1 & 0.6 \\
1 & 0.6667 & 1 & 1 & 1 & 1
\end{array}\right)
$$

Selanjutnya akan dibuat perkalian matriks $\mathrm{W}^{*} \mathrm{R}$ dan penjumlahan hasil perkalian untuk memperoleh alternative terbaik dengan melakukan perangkingan nilai terbesar sebagai berikut:

$$
\begin{aligned}
& \mathrm{V}_{1}=(5)(0.4)+(4)(1)+(4)(0.8)+(4)(0.6)+(4)(0.8)+(4)(0.8)=18 \\
& \mathrm{~V}_{2}=(5)(0.6)+(4)(1)+(4)(0.8)+(4)(0.8)+(4)(1)+(4)(0.6)=19.8 \\
& \mathrm{~V}_{3}=(5)(1)+(4)(0.6667)+(4)(1)+(4)(1)+(4)(1)+(4)(1)=23.66
\end{aligned}
$$

Hasil perangkingan di peroleh V1 $=18, \mathrm{~V} 2=19.8, \mathrm{~V} 3=23.66$, nilai terbesar ada pada alternative V3 (Rosa) adalah alternative yang terpilih sebagai alternative terbaik.

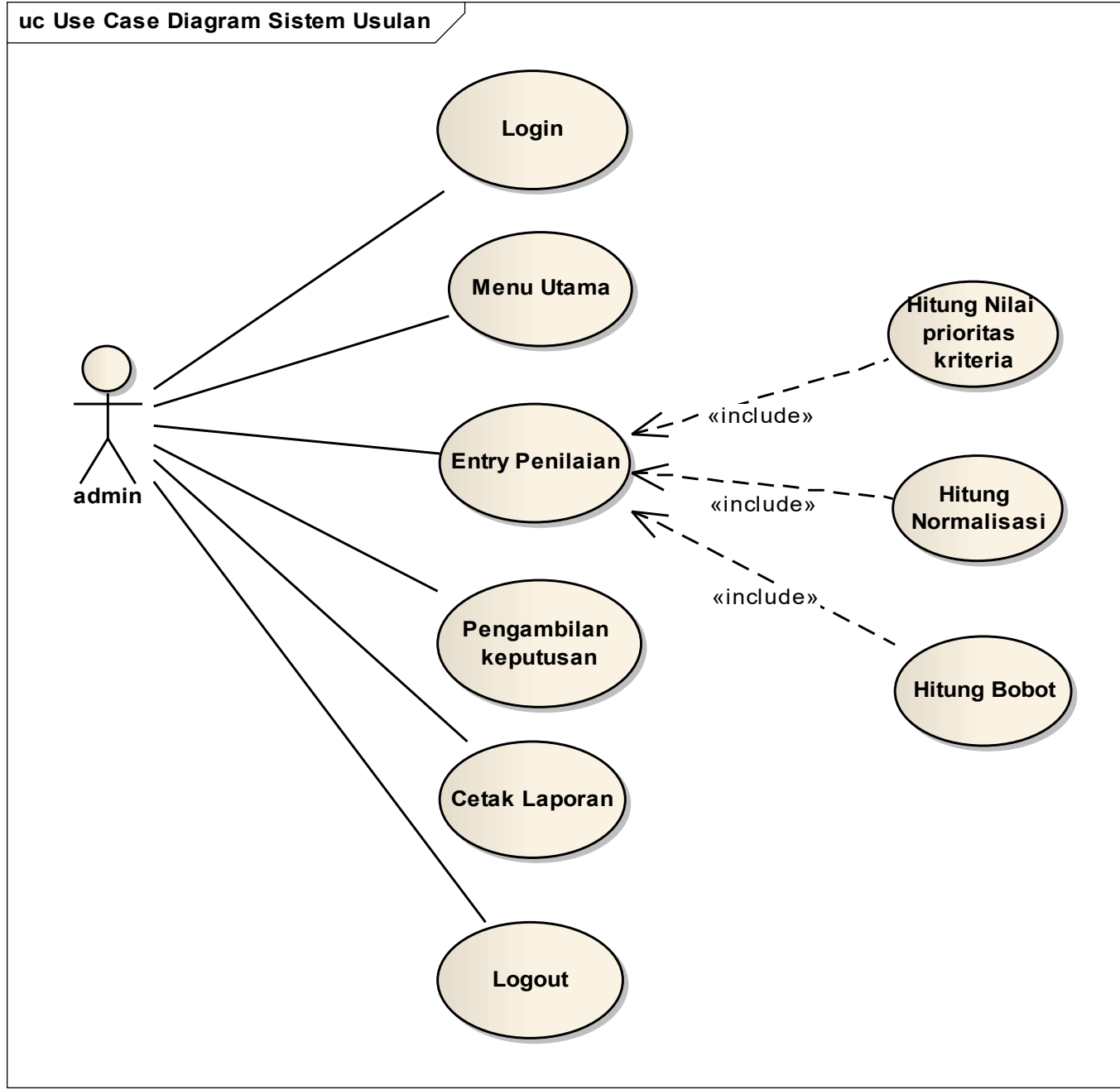

Gambar 2. Use case diagram penilaian kinerja karyawan metode SAW 


\section{Implementasi}

\subsection{Use Case Diagram Sistem Usulan}

Use Case Diagram digunakan untuk menjelaskan apa yang akan dilakukan oleh sistem serta aktoraktor yang akan berhubungan dengan proses-proses yang ada pada sistem. Dalam tahap ini penulis akan membuat Use Case Diagram sistem usulan, seperti pada Gambar 2.

\subsection{Activity Diagram Sistem Usulan}

Activity diagram merupakan diagram yang menggambarkan berbagai aliran aktivitas yang terjadi di dalam sistem, yang meliputi bagaimana sebuah proses dapat terjadi, kemungkinan-kemungkinan yang mungkin bisa terjadi, serta bagaimana akhir dari proses tersebut. Diagram ini sangat mirip dengan flowchart karena dengan activity diagram dapat memodelkan proses logika, proses bisnis, dan alur kerja. Perbedaan utama adalah flowchart dibuat untuk menggambarkan alur kerja dari sebuah sistem, sedangkan activity diagram dibuat untuk menggambarkan aktivitas aktor.

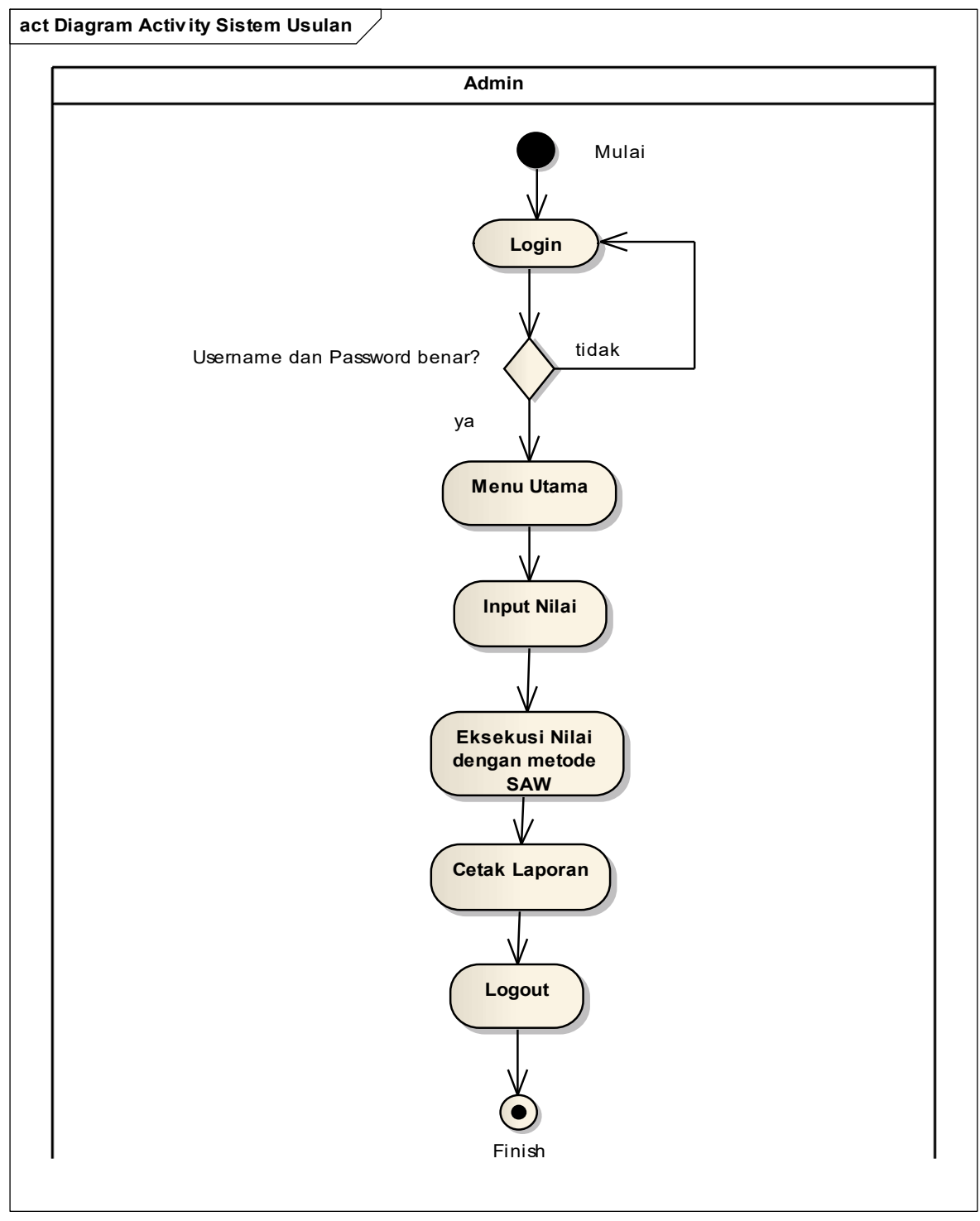

Gambar 3. Activity Diagram Sistem Usulan 
Activity diagram merupakan state diagram khusus, dimana sebagian besar state adalah action dan sebagian besar transisi di trigger oleh selesainya state sebelumnya (internal processing). Oleh karena itu, activity diagram tidak menggambarkan behavior internal sebuah sistem secara eksak, tetapi lebih menggambarkan proses-proses dan jalur-jalur aktivitas dari level atas secara umum. Gambar 3 adalah activity diagram untuk masing-masing use case:

\subsection{Sequence Diagram Sistem Usulan \\ 4.3.1. Sequence Diagram Login}

Squence $\quad$ : Squence Diagram Login.

Actor : Manager.

Deskripsi $\quad:$ Admin dapat menampilkan halaman utama $\rightarrow$ memasukkan username dan password $\rightarrow$ Klik ButtonLogin $\rightarrow$ untuk membuka halaman form penilaian

Squence Diagram Login ditunjukkan pada Gambar 4.

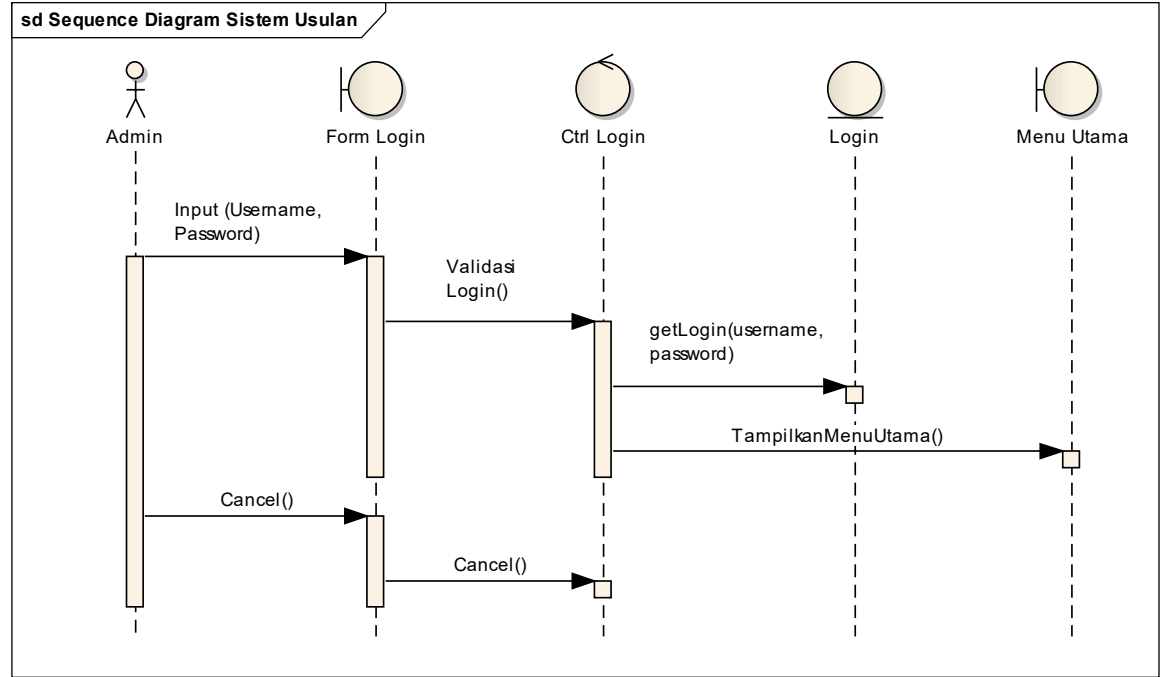

Gambar 4. Sequence Diagram Login

\subsubsection{Sequence Diagram Entry Penilaian}

\section{Squence $\quad$ : Squence Diagram Form Penilaian}

Actor : Admin

Deskripsi : Yaitu,

1. Admin menampilkan form penilaian $\rightarrow$ admin dapat menampilkan data penilaiandan memproses penilaian dengan mengklik tombol proses $\rightarrow$ dan dilanjutkan dengan mengklick button bobot untuk memilih data bobot.

2. Admin dapat mengedit data kriteria dengan mengklik menu ubah dengan memasukkan nilai sesuai dengan keterangan kriteria $\rightarrow$ dan dilanjutkan dengan mengklick button hitung untuk menghitung data kriteria.

3. Admin dapat menghapus data yang telah diinput

Squence Diagram Form Penilaian ditunjukkan pada Gambar 5. 


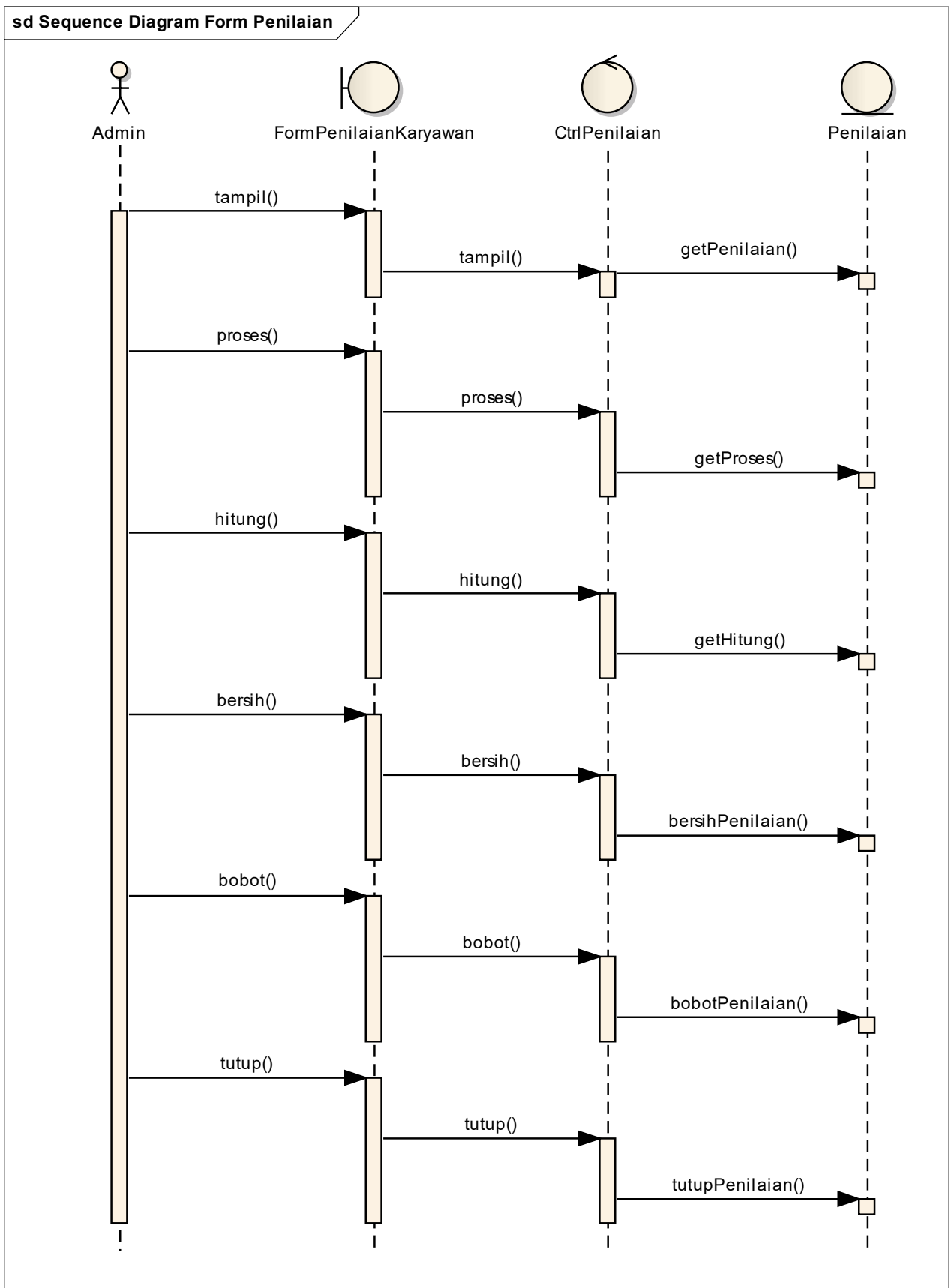

Gambar 5. Sequence Diagram Form Penilaian

\subsubsection{Sequence Diagram SPK}

$\begin{array}{ll}\text { Squence } & : \text { Squence Diagram SPK } \\ \text { Actor } & : \text { Admin } \\ \text { Deskripsi } & : \text { Admin menampilkan form spk } \rightarrow \text { admin dapat melihat nilai kriteria } \rightarrow \text { serta dapat } \\ & \text { memproses normalisasi data dalam form ini } \rightarrow \text { kemudian klik tombol proses untuk } \\ & \text { melihat hasil perkalian hasil normalisasi dengan bobot yang telah di tentukan. }\end{array}$


Squence Diagram SPK ditunjukkan pada Gambar 6.

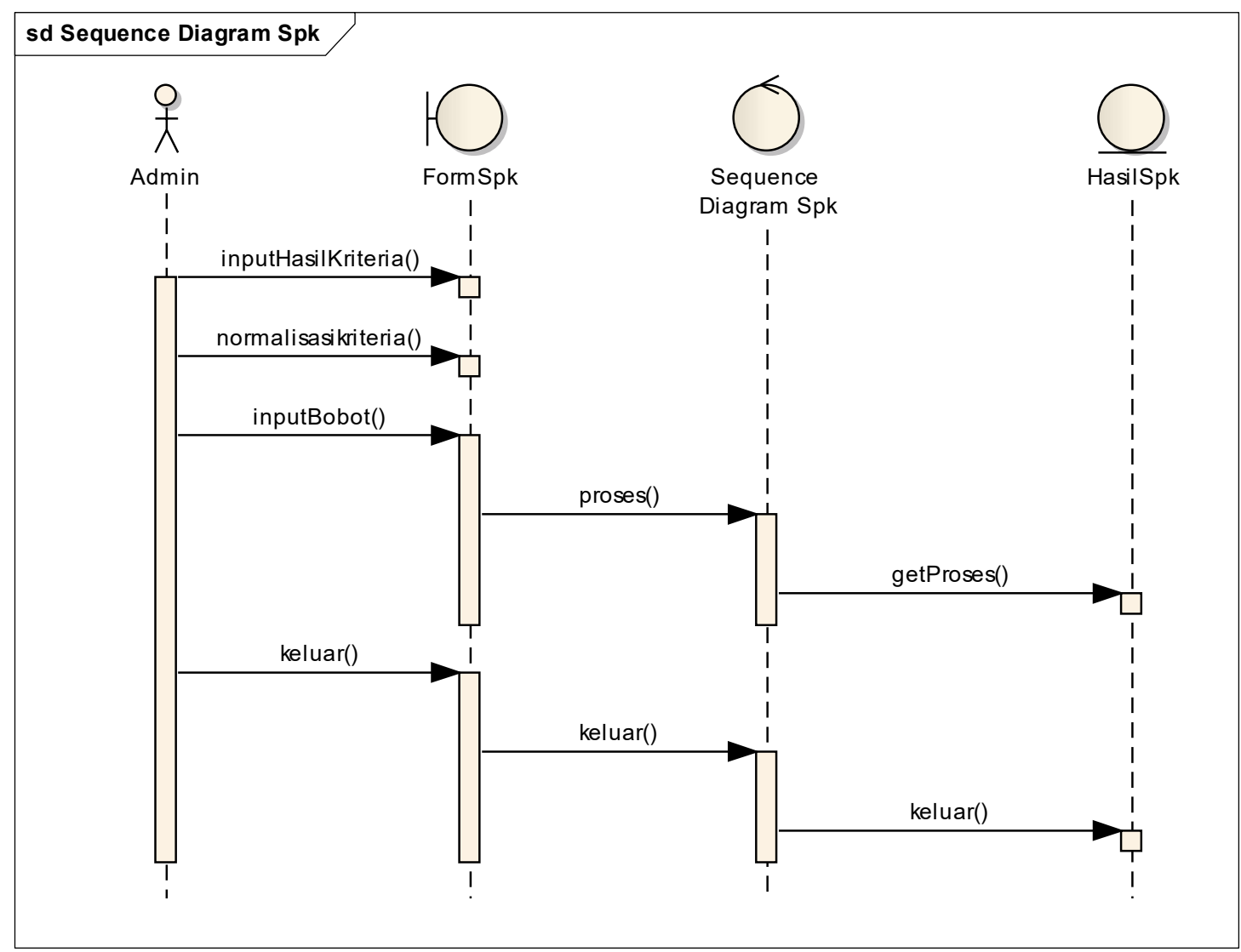

Gambar 6. Sequence Diagram SPK

\subsubsection{Sequence Laporan Penilaian}

Squence $\quad$ : Sequence Laporan Penilaian

Actor : Admin

Deskripsi $\quad$ : Admin dapat mencetak hasil dari penilaian yang sudah diinputnya.

Sequence Laporan Penilaian ditunjukkan pada Gambar 7. 


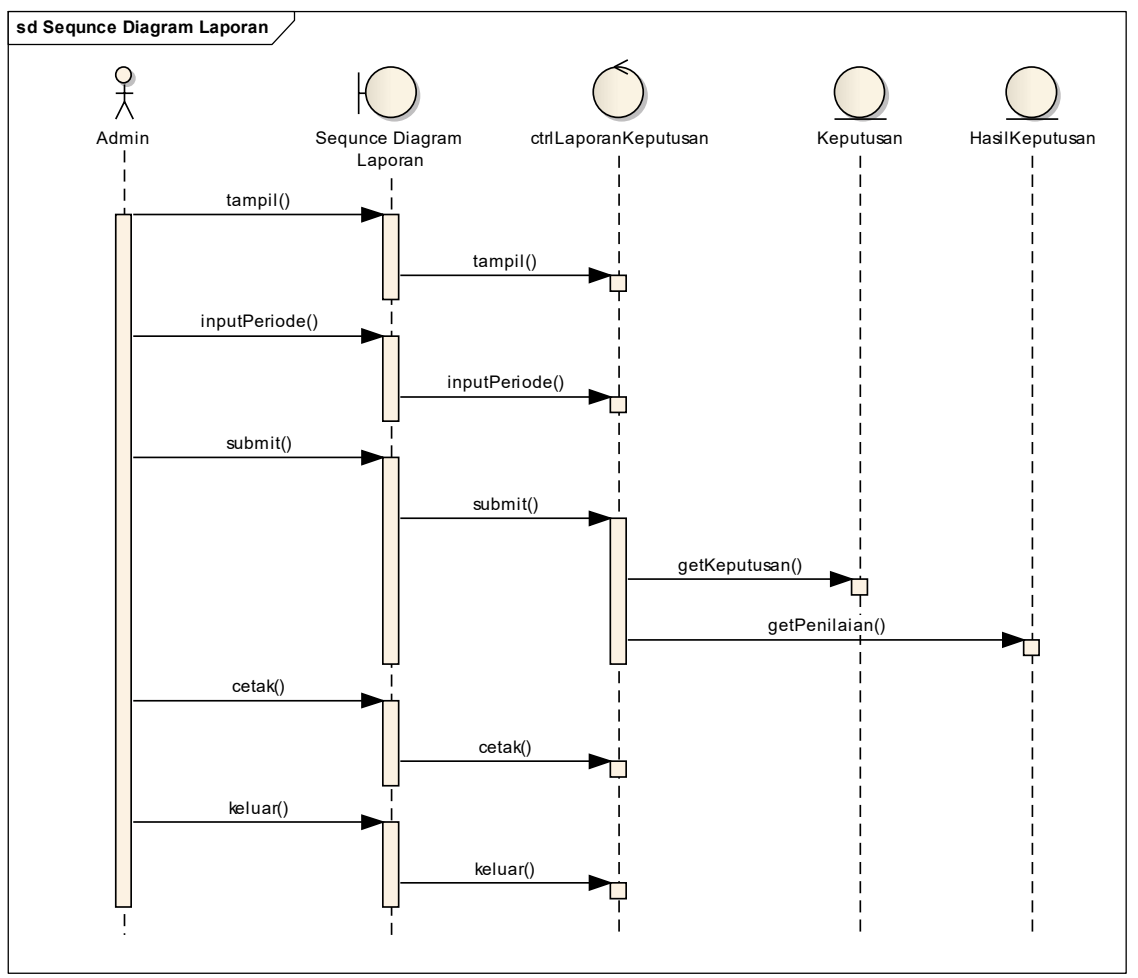

Gambar 7. Sequence Laporan Penilaian

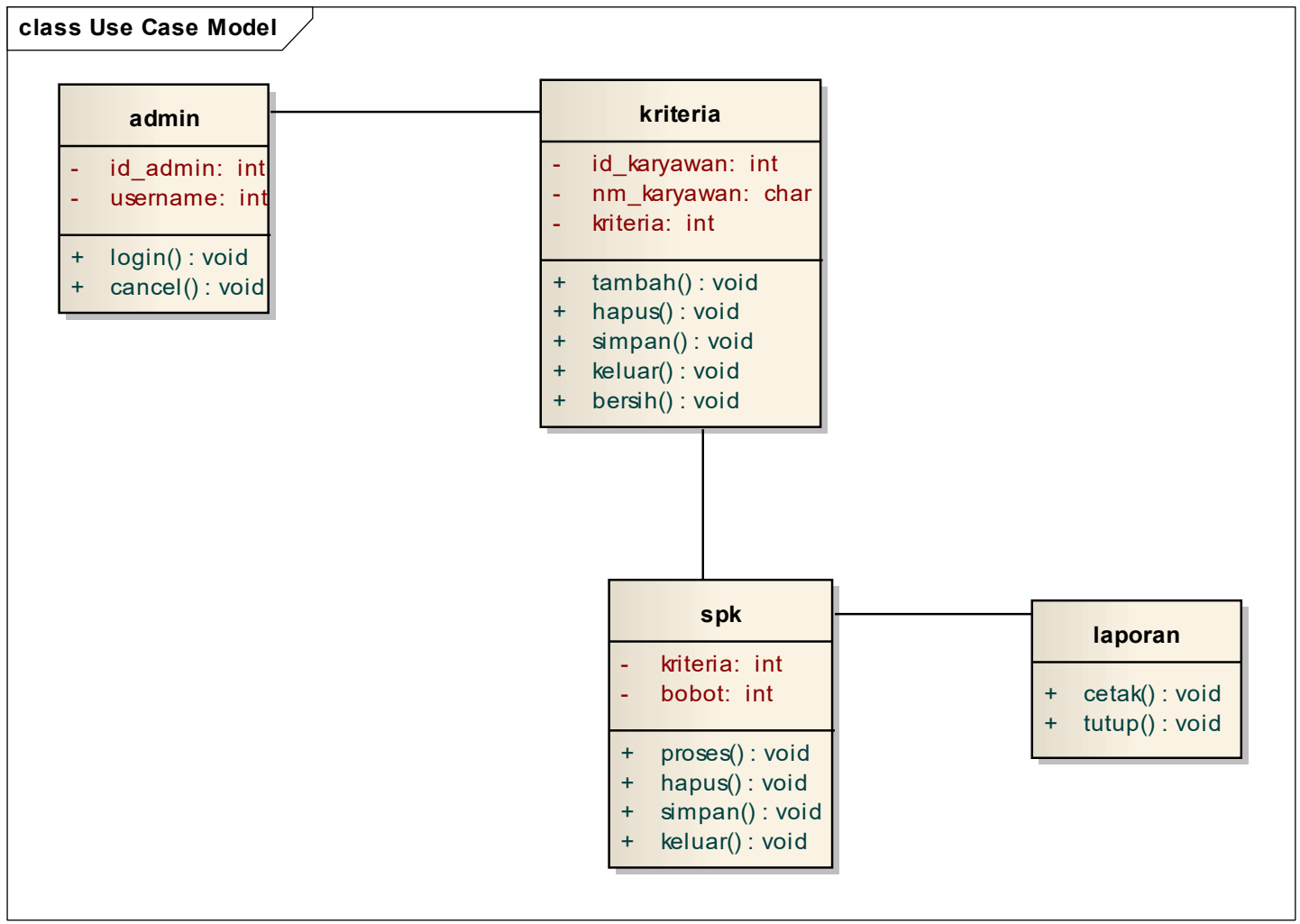

Gambar 8. Class Diagram 


\subsection{Perancangan Class Diagram}

Class Diagram ini digunakan untuk menggambarkan kumpulan dari class dan hubungannya. Diagram ini merupakan diagram yang paling umum ditemukan dalam pemodelan sistem berorientasi objek.Class menggambarkan keadaan suatu sistem, sekaligus layanan untuk memanipulasi keadaan metode atau fungsi sehingga class memiliki tiga area pokok, yaitu: Nama, Atribut, dan Metode. Selain itu setiap class yang ada dapat menjadi sebuah form saat pembuatan program. Class Diagram sistem yang diusulkan dapat dilihat pada Gambar 8 .

\subsection{Rancangan Basis Data: Entity Relationship Diagram}

Entity Relationship Diagram (ERD) atau diagram - ER adalah model teknik pendekatan yang meyatakan atau menggambarkan hubungan suatu model. Didalam hubungan ini tersebut dinyatakan yang utama dari penggambaran diagram - ER adalah menunjukan objek data (entity) dan hubungan (relatioship), yang ada pada entity berikutnya.

\subsection{Normalisasi}

Berikut ini langkah-langkah normalisasi dilakukan dengan diuraikan gambar ketergantungan fungsional dan tahap normalisasi.

\subsubsection{Relasi Kriteria}

Relasi Kriteria ditunjukkan pada Gambar 9.

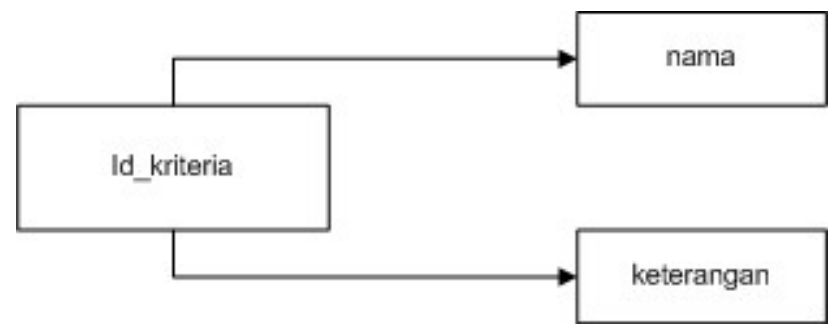

Gambar 9. Relasi Kriteria

Keterangan Gambar:

- Tabel kriteria sudah bernilai tunggal (1NF) karena sudah tidak ada atribut yang berulang (Repeating Group).

- Tabel barang sudah normal bentuk kedua (2NF) karena atribut non key yaitu nama dan keterangan bergantung sepenuhnya kepada atribut key yaitu id_kriteria (Functional Denpendency).

- Tabel barang sudah normal bentuk ke tiga (3NF) karena semua atribut non key tidak bergantung kepada atribut key lainnya tetapi terhadap key yaitu id_kriteria (Transitive Dependency).

\subsubsection{Relasi Alternatif}

Relasi Alternatif ditunjukkan pada Gambar 10.

Keterangan Gambar:

- Tabel alternatif sudah bernilai tunggal (1NF) karena sudah tidak ada atribut yang berulang (Repeating Group).

- Tabel barang sudah normal bentuk kedua (2NF) karena atribut non key yaitu nama dan keterangan bergantung sepenuhnya kepada atribut key yaitu id_alternatif (Functional Denpendency).

- Tabel barang sudah normal bentuk ke tiga (3NF) karena semua atribut non key tidak bergantung kepada atribut key lainnya tetapi terhadap key yaitu id_alternatif (Transitive Dependency). 


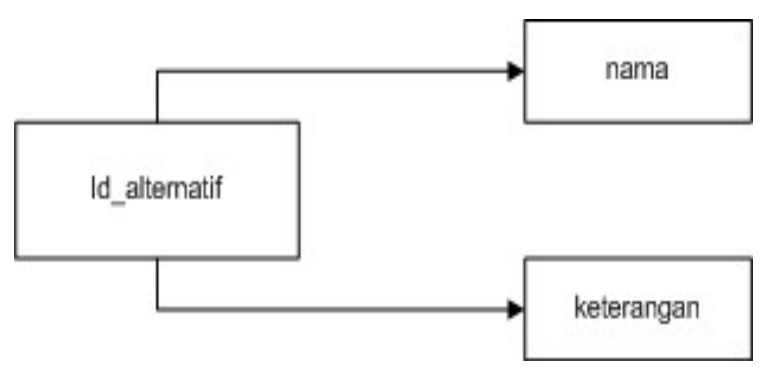

Gambar 10. Relasi Alternatif

\subsubsection{Relasi Kepentingan Kriteria}

Relasi Kepentingan Kriteria ditunjukkan pada Gambar 11.

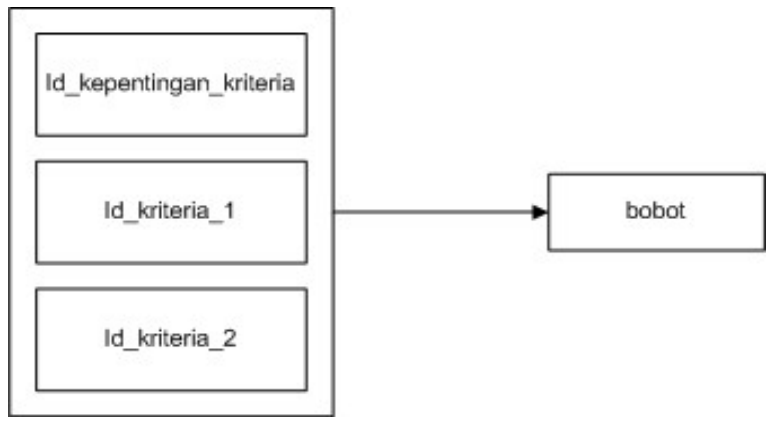

Gambar 11. Relasi Kepentingan Kriteria

Keterangan Gambar:

- Tabel kriteria sudah bernilai tunggal (1NF) karena sudah tidak ada atribut yang berulang (Repeating Group).

- Tabel barang sudah normal bentuk kedua (2NF) karena atribut non key yaitu bobot bergantung sepenuhnya kepada atribut key yaitu id_kepentingan_kriteria, id_kriteria. (Functional Denpendency).

- Tabel barang sudah normal bentuk ke tiga (3NF) karena semua atribut non key tidak bergantung kepada atribut key lainnya tetapi terhadap key yaitu id_kepentingan_kriteria dan id_kriteria (Transitive Dependency).

\subsubsection{Relasi Kepentingan Alternatif}

Relasi Kepentingan Alternatif ditunjukkan pada Gambar 12.

Keterangan Gambar:

- Tabel kriteria sudah bernilai tunggal (1NF) karena sudah tidak ada atribut yang berulang (Repeating Group).

- Tabel barang sudah normal bentuk kedua (2NF) karena atribut non key yaitu bobot bergantung sepenuhnya kepada atribut key yaitu id_kepentingan_alternatif, id_kriteria dan id_alternatif. (Functional Denpendency). 
- Tabel barang sudah normal bentuk ke tiga (3NF) karena semua atribut non key tidak bergantung kepada atribut key lainnya tetapi terhadap key yaitu id_kepentingan_alterantif, id_kriteria dan id_alternatif(Transitive Dependency).

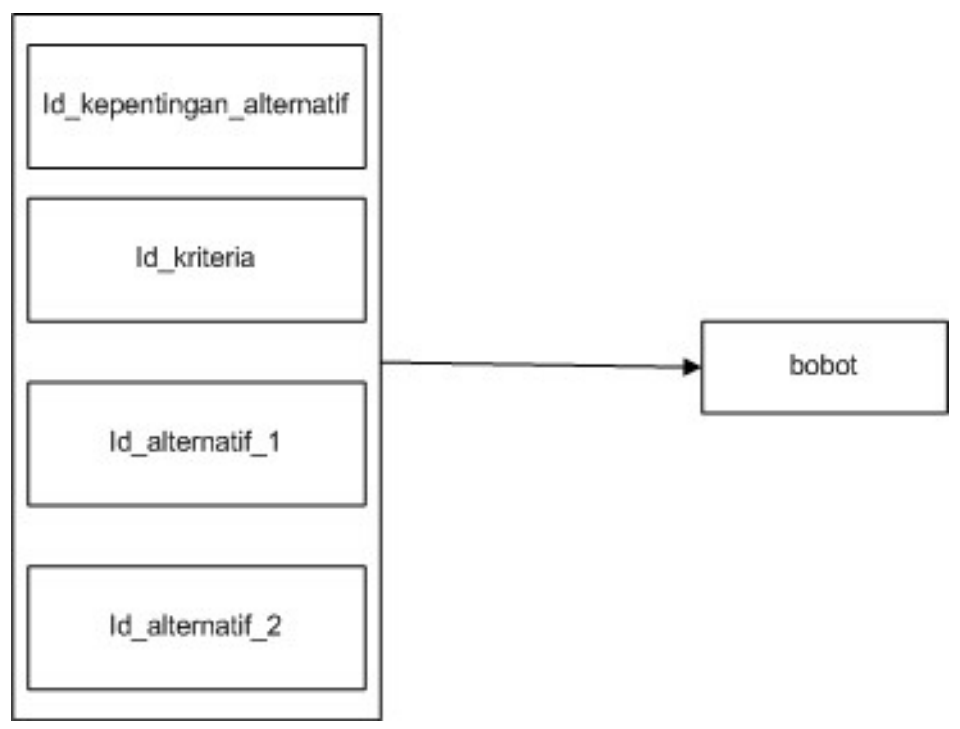

Gambar 12. Relasi Kepentingan Alternatif

\subsection{Implementasi Antar Muka}

Antarmuka dilakukan dengan setiap halaman program yangdibuat dan pengkodeannya dalam bentuk file program. Berikut ini adalah implementasi antarmuka dari sistem pendukung keputusan karyawan terbaik PT. MPP Tangerang:

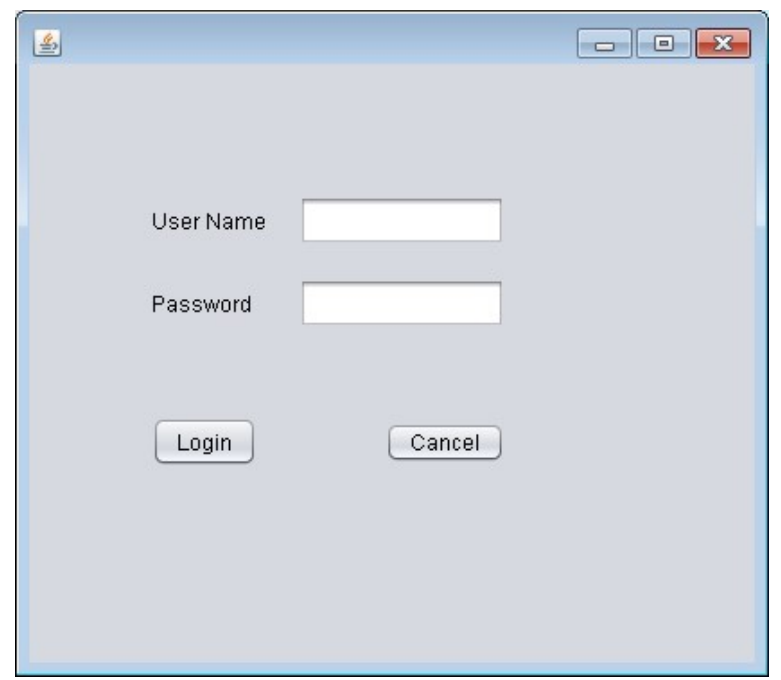

Gambar 13. Gambar Login 


\subsubsection{Halaman login}

Halaman login diimplementasikan oleh form login. Halaman ini menampilkan form login yang harus diisi oleh pengguna ke dalam sistem. Untuk membuka halaman ini pengguna dapat menjalankan aplikasi penilaian karyawan.

Halaman Login ditunjukkan pada Gambar 13.

Proses aunthentifikasi dimulai dengan menampilkan halaman login untuk pengguna yang terdapat masukan username dan password. Ketika pengguna menekan tombol login dan user belum mengisi username atau password maka sistem akan menampilkan pesan yang meminta user untuk mengisi username atau password.

Kesalahan pada pengisian login akan memunculkan warning seperti Gambar 14.

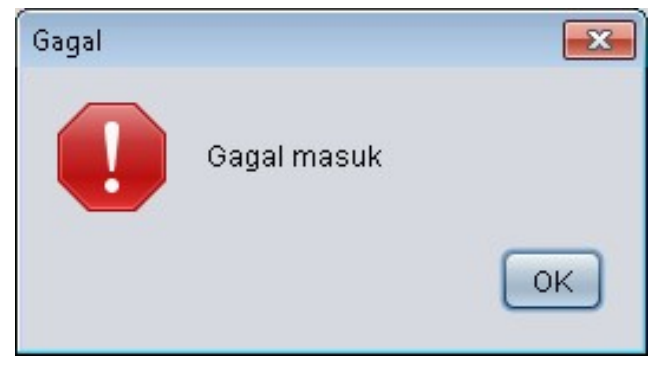

Gambar 14. Gambar Gagal Login

Jika aunthenfikasi benar maka sistem akan menampilkan pesan seperti gambar di bawah ini

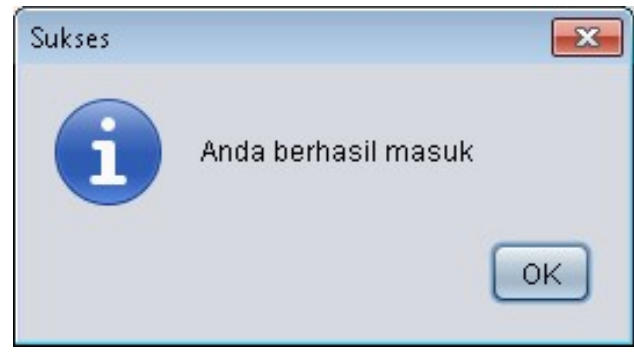

\section{Gambar 15. Gambar Berhasil Login}

Jika user ingin membatalkan login dengan mengklik tombol cancel maka sistem akan menampilan pesan seperti pada Gambar 16.

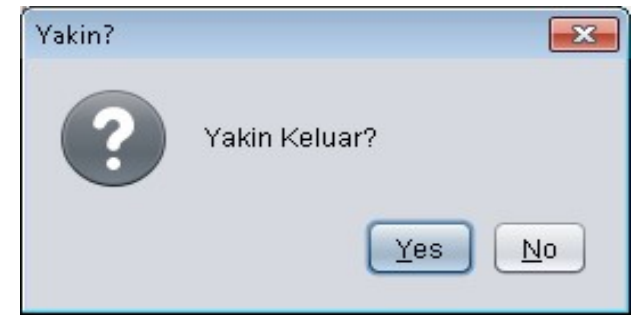

Gambar 16. Gambar Cancel 


\subsection{Halaman Penilaian}

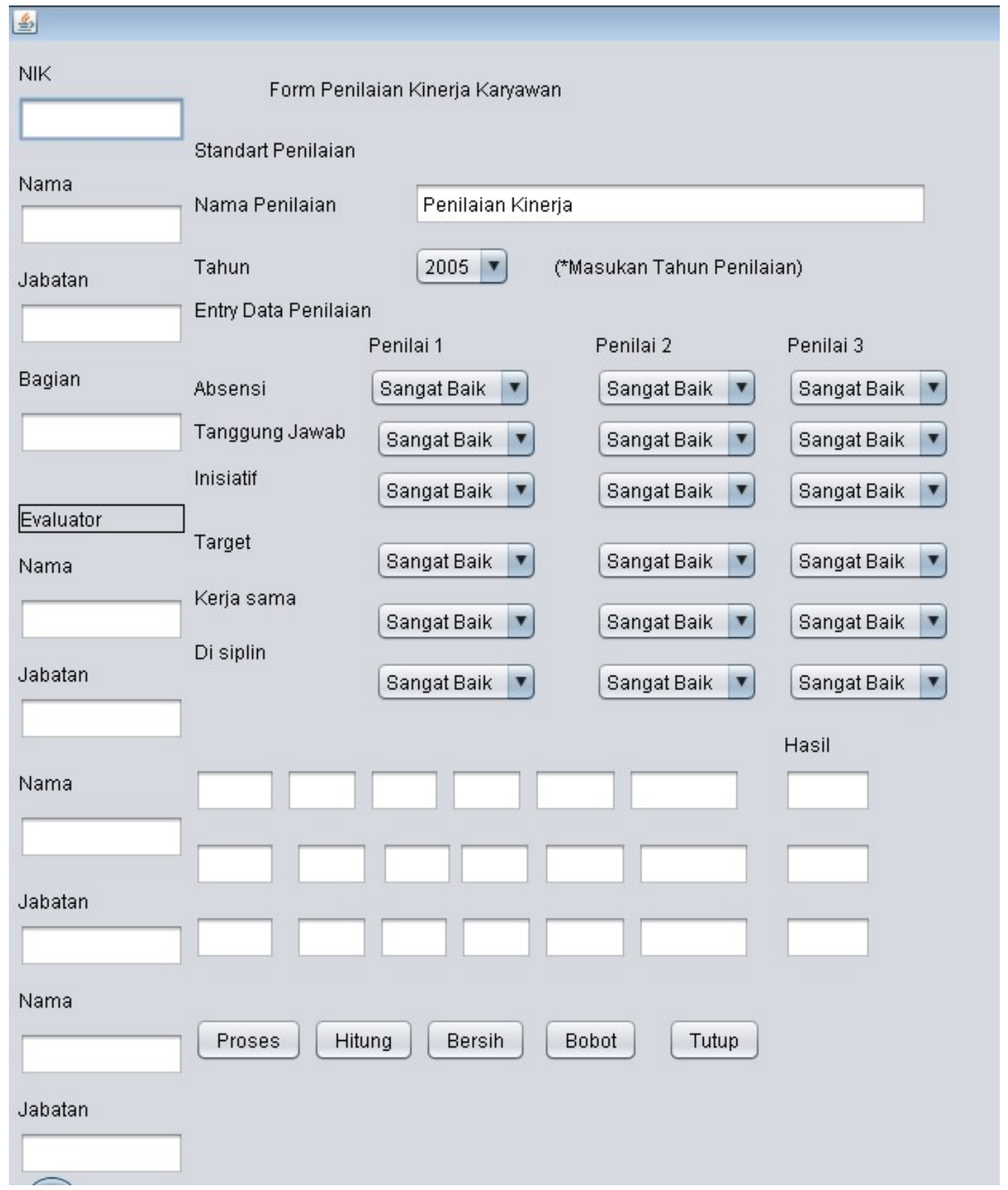

\section{Gambar 17. Gambar Penilaian}

Tampilan dari penilaian pada Gambar 17, user memasukan nama karyawan yang akan di nilai dari masing-masing penilan. 


\subsection{Halaman Bobot}

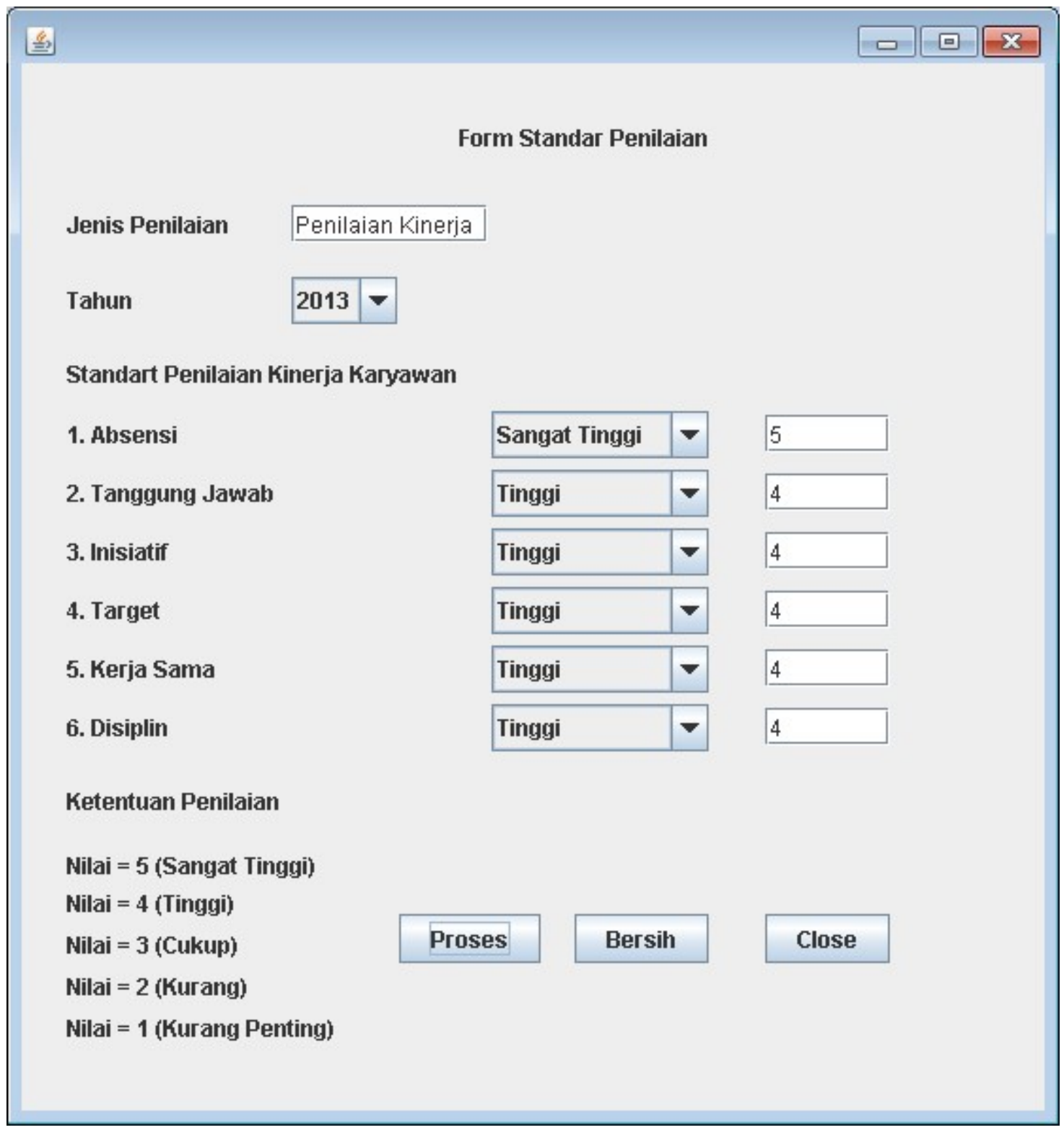

Gambar 18. Gambar Bobot

Di dalam tampilan bobot ini adalah bobot yang telah di tentukan oleh perusahaan di mana setiap kriteria bobot memiliki tingkat kepentingan yang berbeda. 


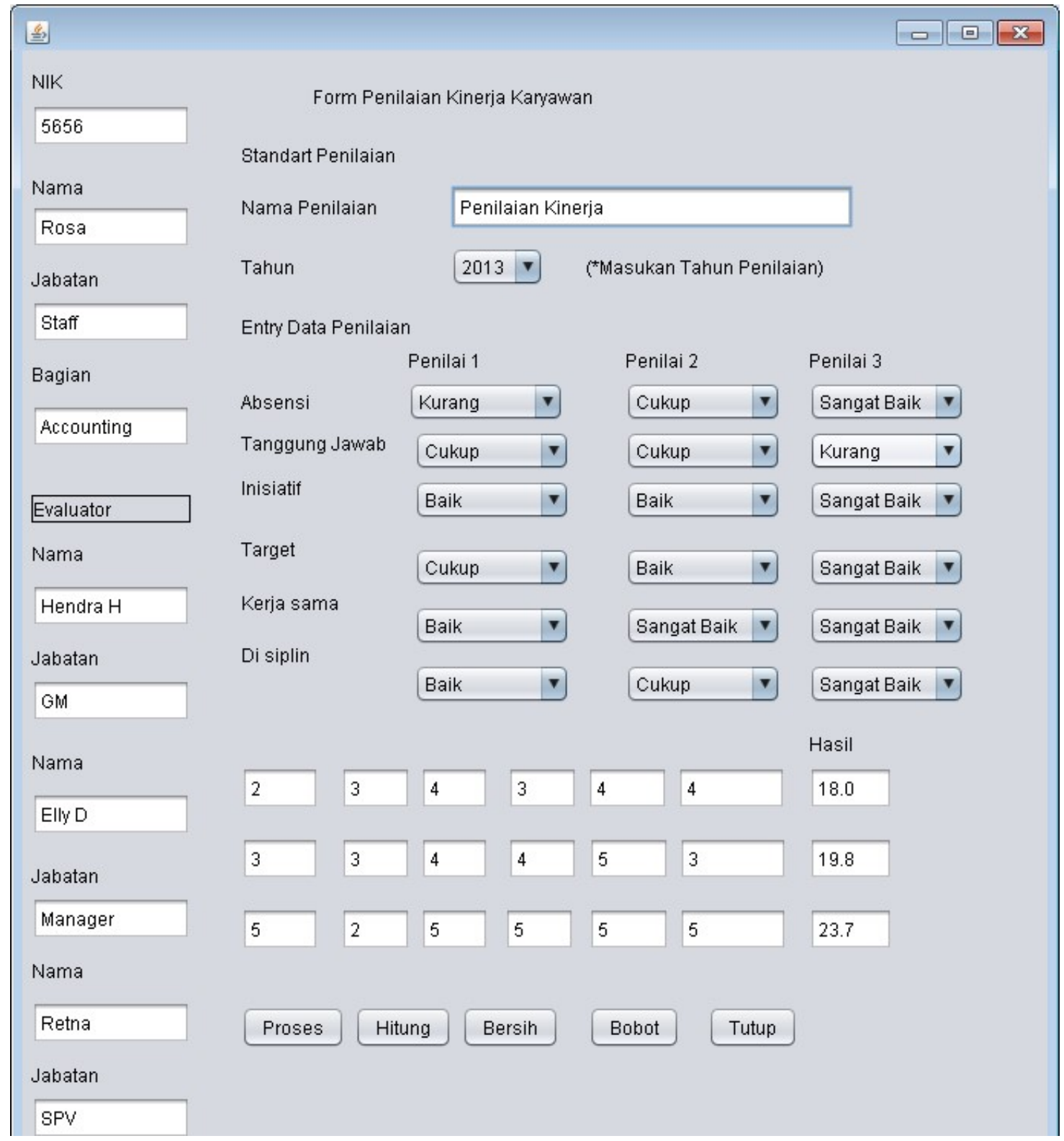

Gambar 19. Hasil Penilaian dan perkalian bobot

Tampilan penilaian di atas merupakan hasil input admin untuk menentukan penilaian mana yang paling tinggi. Maka nilai tertinggi yang di berikan adalah dari penilai ketiga

\section{Pengujian}

Proses pengujian adalah mencoba program dengan memasukkan datakedalam form-form masukan yang telah disediakan. Pada tahap ini merupakankelanjutan dari tahap implementasi yaitu melakukan pengujian-pengujian terhadap aplikasi yang dibangun.

Rencana Pengujian yang akan dilakukan dengan menguji sistem yang dibangun secara alpha dan beta. Pengujian Sistem Pendukung Keputusan Penilaian Kinerja Karyawan Berprestasi Menggunakan metode Simple Additive Weighting (SAW) menggunakan data uji berdasarkan data yang diberikan dari Pihak MPP Tangerang. Rencana pengujian selengkapnya terlihat pada Tabel 10. 
Tabel 10. Rencana Pengujian

\begin{tabular}{|c|l|c|}
\hline ITEM UJI & DETAIL PENGUJIAN & JENIS UJIAN \\
\hline Login & Verifikasi Kode & Black Box \\
\hline Ubah Password & Ubah & Black Box \\
\hline Data Bobot & Proses, Bersih, Close & Black Box \\
\hline Data Kriteria & $\begin{array}{l}\text { Proses, Hitung, Bersih, } \\
\text { Bobot, Tutup }\end{array}$ & Black Box \\
\hline
\end{tabular}

\subsection{Pengujian Alpha}

Berdasarakan rencana pengujian yang telah disusun, maka dapat dilakukan pengujian alpha sebagai berikut.

\subsubsection{Pengujian login}

Tabel 11. Pengujian Login Benar

\begin{tabular}{|l|l|}
\hline \multicolumn{2}{|c|}{ KASUS DAN HASIL UJI (DATA NORMAL) } \\
\hline Data masukkan & Username, Password terdaftar \\
\hline Yang diharapkan & $\begin{array}{l}\text { Data login dimasukkan, isi username dan password lalu klick login maka } \\
\text { akan dilalukan proses pengecekan data login, apabila login benar maka akan } \\
\text { menampilkan halaman admin. }\end{array}$ \\
\hline Pengamatan & Dapat mengisi data login sesuai dengan yang diharapkan. \\
\hline Kesimpulan & Sukses. \\
\hline
\end{tabular}

Tabel 12. Pengujian Login Salah

\begin{tabular}{|l|l|}
\hline \multicolumn{2}{|c|}{ KASUS DAN HASIL UJI (DATA SALAH) } \\
\hline Data masukkan & Username dan Password tidak terdaftar \\
\hline Yang diharapkan & $\begin{array}{l}\text { Data login tidak terdaftar maka akan menampilkan kesalahan dan kembali } \\
\text { pada halaman depan. }\end{array}$ \\
\hline Pengamatan & $\begin{array}{l}\text { Operator tidak bisa melakukan login, menampilkan pesan dan kembali } \\
\text { kehalaman depan yang disesuaikan. }\end{array}$ \\
\hline Kesimpulan & Sukses. \\
\hline
\end{tabular}




\subsubsection{Pengujian Data Kriteria}

Berdasarkan hasil pengujian dengan kasus sample uji yang telah dilakukan memberikan kesimpulan bahwa pada proses masih memungkinkan untuk terjadinya kesalahan pada sintaks karena penyaringan proses dalam bentuk arahan tampilan message box belum maksimal diciptakan dan ditampilkan tetapi secara fungsional sistem sudah dapat menghasilkan output yang diharapkan walaupun belum begitu sempurna.

Tabel 13. Pengujian Data Kriteria Benar

\begin{tabular}{|l|l|}
\multicolumn{2}{|c|}{ TAMBAH DATA KRITERIA } \\
\hline \multicolumn{1}{|c|}{ KASUS DAN HASIL UJI (DATA NORMAL) } \\
\hline Data masukkan & Menambah data kriteria. \\
\hline Yang diharapkan & $\begin{array}{l}\text { Saat dimasukkan data kriteria lalu klik prosesdan data memproses kriteria } \\
\text { yang telah dipilih }\end{array}$ \\
\hline Pengamatan & Data muncul di dalam textfielddalam bentuk angka \\
\hline Kesimpulan & Sukses. \\
\hline & \multicolumn{1}{|c|}{ BERSIH DATA KRITERIA } \\
\hline Data masukkan & Membersihkan data yang sudah dipilih berdasarkan penilaian \\
\hline Yang diharapkan & Proses membersihkan data yang benar, klik ubah \\
\hline Pengamatan & Data kosong \\
\hline Kesimpulan & Sukses. \\
\hline & \multicolumn{1}{|c|}{ HITUNG } \\
\hline Kesimpulan & Sukses. \\
\hline Yang diharapkan & $\begin{array}{l}\text { Saat mengklik hitung data menghasilkan hasil yang sudah sikalikan dengan } \\
\text { bobot terpilih. }\end{array}$ \\
\hline Pengamatan & Data menghasilkan hasil akhir \\
\hline
\end{tabular}

\subsection{Pengujian Beta}

Pengujian beta adalah pengujian yang dilakukan secara objektif dimana diuji secara langsung ke lapangan. Dengan membuat kuesioner mengenai kegunaan sistem yang dibangun, apakah sistem tersebut sudah dapat memberikanapa yang diinginkan oleh pengguna atau belum. Untuk kuisioner pengujian beta dari aplikasi SPK penerimaan Foreman dari karyawan mekanik terbaik ini dapat dilihat pada bagian lampiran. Berdasarkan data hasil kuisioner, dapat dicari presentase masing-masing jawaban dengan menggunakan Persamaan: 


$$
\mathrm{Y}=\mathrm{P} / \mathrm{Q} * 100 \%
$$

Keterangan:

$\mathrm{P}=$ Banyaknya jawaban responden tiap soal

$\mathrm{Q}=$ Jumlah responden

$\mathrm{Y}=$ Nilai Presentase

Berikut kuesioner yang diberikan kepada responden untuk pengujian beta dari aplikasi SPK Pemilihan Foreman dari karyawan mekanik terbaik.

\section{Pertanyaan 1}

Apakah Aplikasi ini mempermudah perhitungan dalam pemilihan karyawan berprestasi?

Tabel 14. Pertanyaan 1

\begin{tabular}{|l|l|l|l|}
\hline Katagori Jawaban & $\begin{array}{c}\text { Frekuensi } \\
\text { Jawaban }\end{array}$ & $\begin{array}{c}\text { Jumlah Populasi } \\
\text { Sampel }\end{array}$ & Jumlah Presentase \\
\hline Sangat bagus & & & \\
\hline Bagus & & & \\
\hline Cukup bagus & & & \\
\hline Kurang bagus & & & \\
\hline Sangat tidak bagus & & & \\
\hline
\end{tabular}

Pertanyaan 2

Sistem Pendukung Keputusan ini dapat menghasilkan keputusan dan informasi yang diinginkan oleh pihak HRD?

Tabel 15. Pertanyaan 2

\begin{tabular}{|l|l|l|l|}
\hline Katagori Jawaban & $\begin{array}{c}\text { Frekuensi } \\
\text { Jawaban }\end{array}$ & $\begin{array}{c}\text { Jumlah Populasi } \\
\text { Sampel }\end{array}$ & Jumlah Presentase \\
\hline Sangat setuju & & & \\
\hline Setuju & & & \\
\hline Cukup & & & \\
\hline Kurang setuju & & & \\
\hline Sangat tidak setuju & & & \\
\hline
\end{tabular}

Pertanyaan 3

Apakah struktur dari aplikasi ini mudah untuk dipelajari (User Friendly)?

Tabel 16. Pertanyaan 3

\begin{tabular}{|l|l|l|l|}
\hline \multicolumn{1}{|c|}{ Katagori Jawaban } & $\begin{array}{c}\text { Frekuensi } \\
\text { Jawaban }\end{array}$ & $\begin{array}{c}\text { Jumlah Populasi } \\
\text { Sampel }\end{array}$ & Jumlah Presentase \\
\hline Sangat akurat & & & \\
\hline Akurat & & & \\
\hline Cukup akurat & & & \\
\hline Kurang akurat & & & \\
\hline Sangat tidak akurat & & & \\
\hline
\end{tabular}




\section{Pertanyaan 4}

Apakah Sistem Pendukung keputusan ini dapat mempercepat proses penilaian kinerja karyawan?

Tabel 17. Pertanyaan 4

\begin{tabular}{|l|l|l|l|}
\hline Katagori Jawaban & $\begin{array}{c}\text { Frekuensi } \\
\text { Jawaban }\end{array}$ & $\begin{array}{c}\text { Jumlah Populasi } \\
\text { Sampel }\end{array}$ & Jumlah Presentase \\
\hline Sangat setuju & & & \\
\hline Setuju & & & \\
\hline Cukup & & & \\
\hline Kurang setuju & & & \\
\hline Sangat tidak setuju & & & \\
\hline
\end{tabular}

\section{Pertanyaan 5}

Apakah dengan adanya Sistem Pendukung Keputusan ini memberikan kemudahan dalam membuat laporan?

Tabel 18. Pertanyaan 5

\begin{tabular}{|l|l|l|l|}
\hline Katagori Jawaban & $\begin{array}{c}\text { Frekuensi } \\
\text { Jawaban }\end{array}$ & $\begin{array}{c}\text { Jumlah Populasi } \\
\text { Sampel }\end{array}$ & Jumlah Presentase \\
\hline Sangat setuju & & & \\
\hline Setuju & & & \\
\hline Cukup & & & \\
\hline Kurang setuju & & & \\
\hline Sangat tidak setuju & & & \\
\hline
\end{tabular}

Dari hasil pengujian betha yang telah dilakukan yaitu dengan pengujianperhitungan pilihan kategori jawaban dari kuesioner yang telah dibagikan dilapangan didapat kesimpulan bahwa program aplikasi yaitu Sistem PendukungKeputusan kinerja karyawan ini dinilai memiliki tampilan yangmenarik, mudah digunakan, hasil yang diperoleh mendekati dengan hasil yangdikeluarkan dengan penghitungan manual, pengolahan data dan informasi dapat dilakukandengan cepat dan dapat membantu dalam proses pengolahan data hasil keputusan.

\section{Kesimpulan}

Bedasarkan hasil analisa dan perancangan serta pengujian sistem yang telah dilakukan pada Penilaian Kinerja karyawan di PT.MPP maka penulis dapat mengambil kesimpulan bahwa dengan penggunaan metode Simple Additive Weighting (SAW) menjadi lebih efektif untuk melakukan penilaian kinerja karyawan. Sistem memberikan solusi rekomendasi karyawan terbaik kepada pengguna (user) sesuai dengan kriteria dan bobot yang ditentukan diawal sebelum perhitungan.

Setelah mengembangkan sistem pendukung keputusan ini, ada beberapa saran yang harus diterapkan guna pengembangan sistem pendukung keputusan lebih lanjut:

1. Penulis menyarankan untuk penelitian selanjutnya sistem ini bisa berkembang,

2. Perlu dilakukan pemeliharaan dan pengawasan dari pihak yang bertanggung jawab terhadap sistem;

3. Kiranya pengembangan program aplikasi sistem pendukung keputusan ini dapat dijadikan media yang tepat bagi penggunanya, dalam menerima informasi yang akurat, terpercaya, dan memiliki nilai yang efektif serta efisien bagi pengguna. 


\section{Daftar Pustaka}

[1] Rudianto. (2006). Akuntansi Manajemen Untuk Pengambilan Keputusan. Jakarta: PT.Grasindo.

[2] Hasibuan, M.S.P. (2003). Manajemen Sumber Daya Manusia. Jakarta: Bumi Aksara

[3] Marwansyah. (2010). Manajemen Sumber Daya Manusia Edisi Revisi. Bandung: Alfabeta.

[4] Mubarak, R. (2010). Sistem Cerdas Berbasis Konsep Fuzzy Logic. Jakart: Tesis, Program Studi Teknik Informatika, Program Pasca Sarjana (S2) Magister Komputer, Sekolah Tinggi Manajemen Informatika dan Komputer Eresha.

[5] Kusumadewi, S. (2006). Fuzzy Multi-Atrribute Decision Making. Yogyakarta: Graha Ilmu.

[6] Kiswanto, H. (2010). Penilaian Kinerja Karyawan Dengan Metode Fuzzy Multi Criteria Decision Making Menggunakan Microsoft Visual C\# 2010 Dan Sql Server 2008 R2 (Study Kasus : PT. ISTW Semarang). Jurnal TransIT 1(1).

[7] Maulana, K. (2011). Sistem Pendukung Keputusan Penilaian Karyawan Berprestasi Berdasarkan Kinerja Berbasis Web Dengan Metode Analytical Hierarchy Process (AHP): Studi kasus pada PT Anindya Mitra Internasional Yogyakarta. Yogyakarta: Skripsi, Jurusan Tehnik Informatika, Fakultas Teknologi Industri, Universitas Pembangunan Nasional "VETERAN".

[8] Widyarachmawati, E. (2012). Rancangan Bangun Sistem Pendukung Keputusan Penilaian Kinerja Karyawan Menggunakan Metode Simple Additive Weighting (Studi Kasus: PT. Persero Angkasa Pura Bandar Udara Juanda Surabaya). Surabaya: Skripsi, Sekolah Tinggi Manajemen Informatikan dan Teknik Komputer Surabaya.

[9] Komarudin, G. A. (2012). Sistem Pendukung Keputusan Pemilihan balai Pengobatan Menggunakan Fuzzy Multiple AttributeDecission Making (FMADM) (Studi Kasus : Kota Cimahi). Seminar Nasional Ilmu Komputer Universitas Diponegoro. Yogyakarta: Graha Ilmu.

[10] Idris, S. A. (2012). Analisis Perbandingan Metode Analytical Hierarchy Process (Ahp) Dan Simple Additive Weighting (SAW). Skripsi, program Studi Sistem Infomasi, Fakultas Tehnik, Universitas Negeri Gorontalo.

[11] Prawirosentono, S. (2008). Manajemen Sum berdaya Manusia Kebijakan Kinerja Karyawan.Yogyakarta: BPFE.

[12] Roziqin, M. Z. (2010). Kepuasan Kerja. Malang: Averroes Press.

[13] Wirawan. (2009). Evaluasi Kinerja Sumber Daya Manusia. Jakarta: Salemba Empat

[14] Munafiah, S. (2011). Pengaruh Kompensasi dan Supervisi terhadap Kinerja Karyawan (Studi Kasus pada PT. Industri Sandang Nusantara Unit Patal Secang). Skripsi, FE Universitas Negeri Yogyakarta.

[15] Chalid, I. R. (2009). Aplikasi Audio Steganografi Untuk Melindungi Data Menggunakan Bahasa Pemrograman Java 3. Skripsi, Fakultas Teknologi Industri, Universitas Gunadarma.

[16] Kadir, A. (2003). Dasar Pemrograman Java 2. Yogyakarta: Penerbit Andi 